Universidad de Lima

Facultad de Comunicación

Carrera de Comunicación

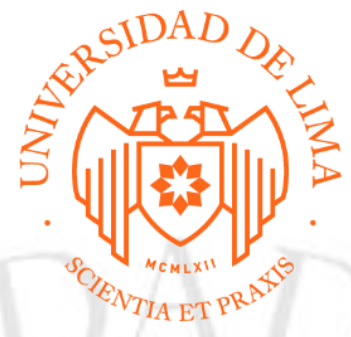

\title{
LANZAMIETO DE QUNTU, COCENTRADO DE CHICHA MORADA
}

Trabajo de Suficiencia Profesional para optar el Título Profesional de Licenciado en Comunicación

\section{Mayra Lizeth Vallejos Malpartida \\ Código 20102775 \\ Sofia Liliana Servan Lira \\ Código 20112360}

\author{
Lima - Perú \\ Mayo de 2019
}




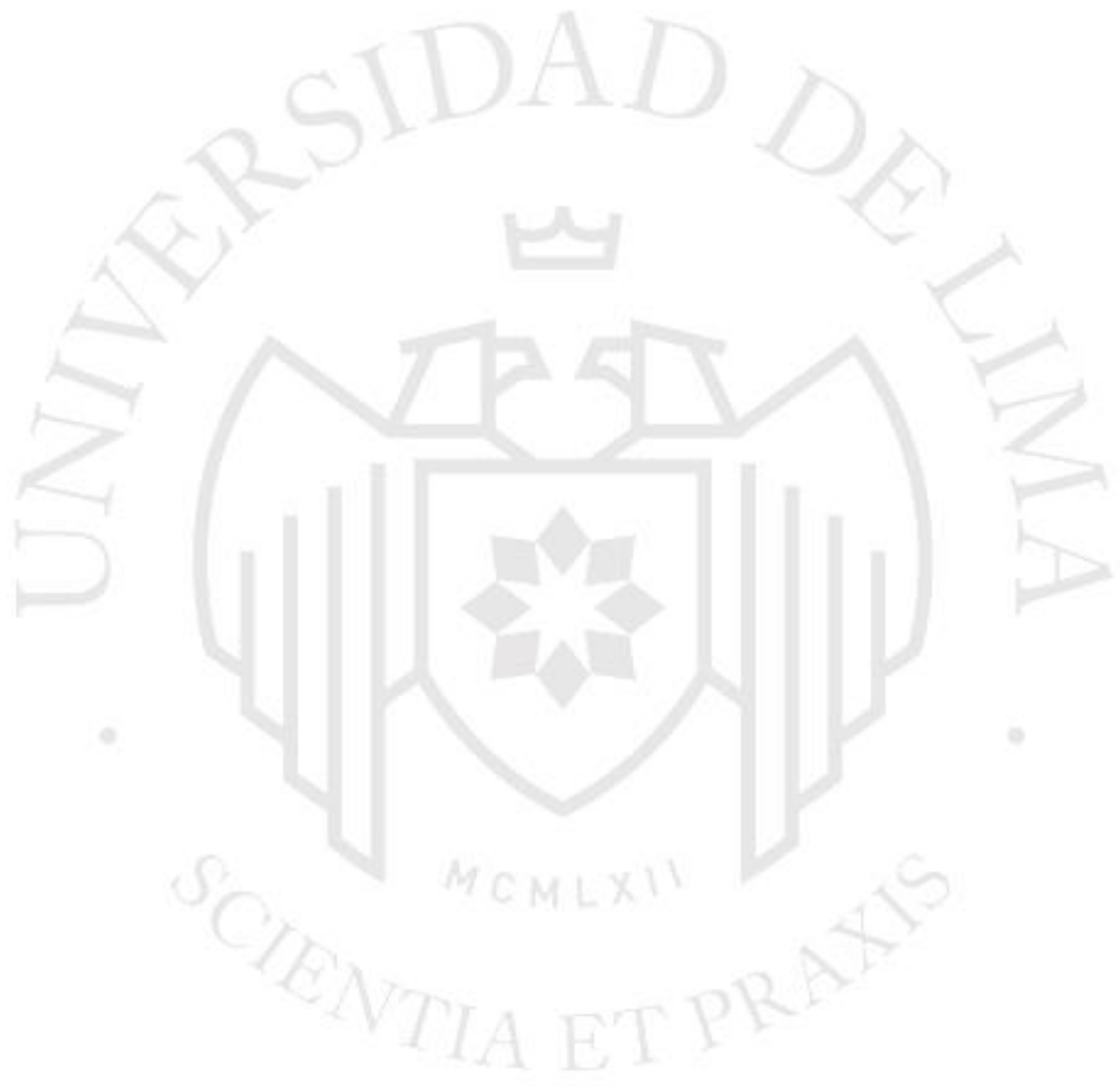




\section{LANZAMIENTO DE QUNTU, CONCENTRADO DE CHICHA MORADA}




\section{ÍNDICE}

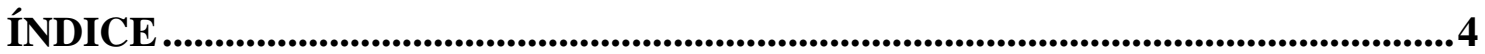

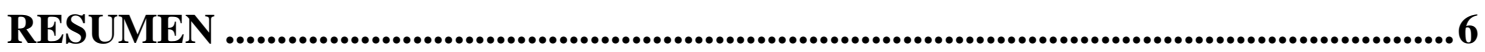

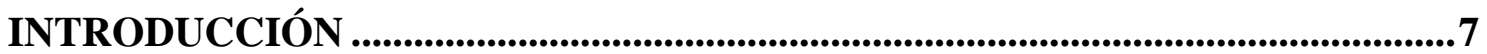

1. ANTECEDENTES DEL TRABAJO.....................................................8

1.1. Descripción del producto .......................................... 8

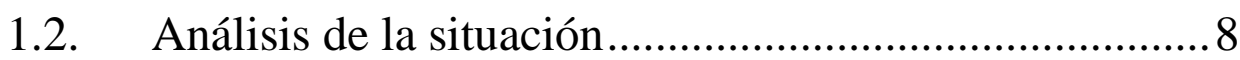

1.2.1. Situación actual del Mercado .......................................... 8

1.2.2. Situación actual de la industria.......................................11

2. EL PÚBLICO OBJETIVO .........................................................16

2.1. Las amas de casa modernas.........................................16

2.2. Comportamiento del público objetivo............................16

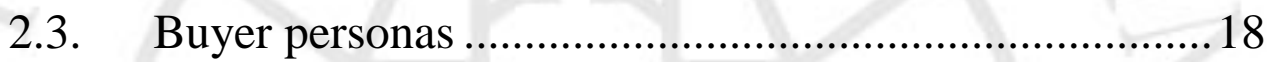

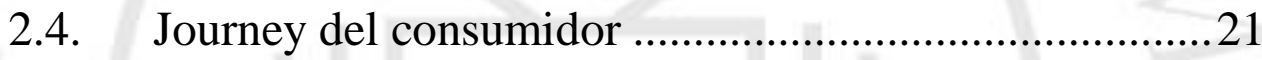

3. PROPUESTA DE COMUNICACIÓN .........................................22

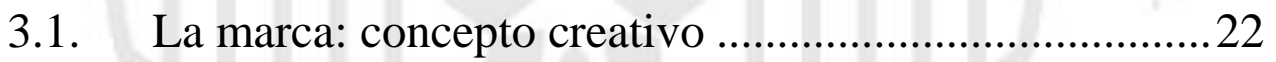

3.2. Identidad de marca ....................................................22

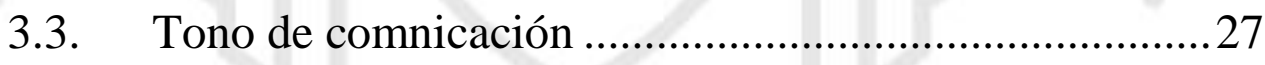

4. CAMPAÑA DE LANZAMIENTO................................................28

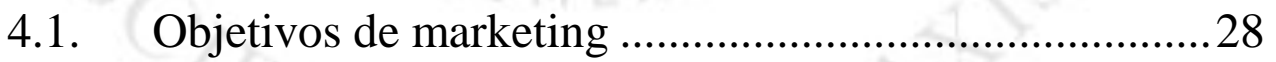

4.2. Objetivos de comunicación ...........................................28

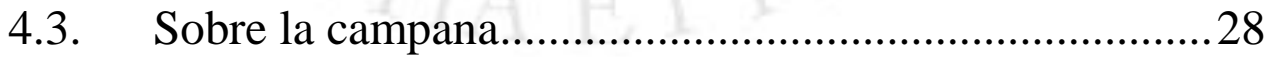

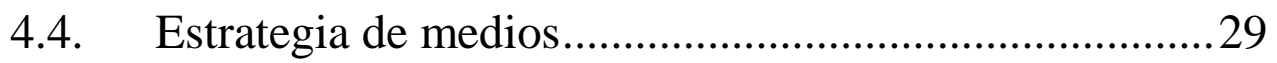

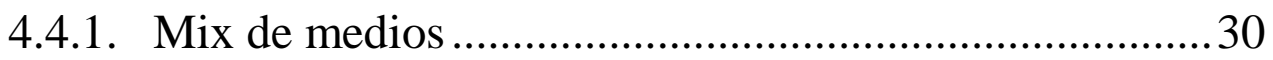

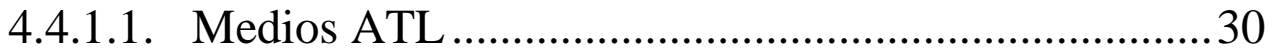

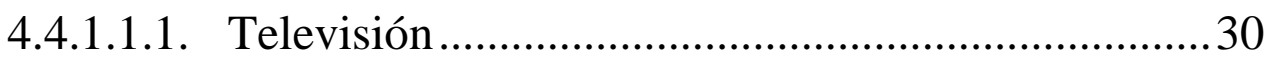

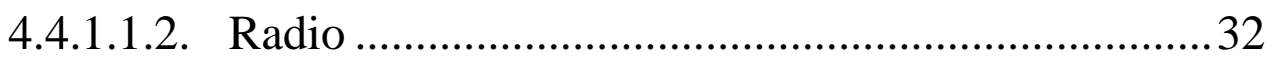

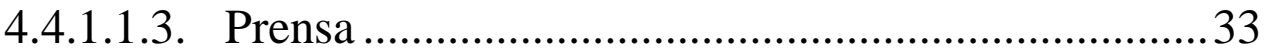




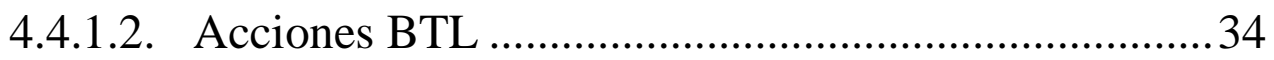

4.4.1.2.1. Experiencias con el producto ....................................34

4.4.1.2.2. Publicidad fuera de casa...........................................36

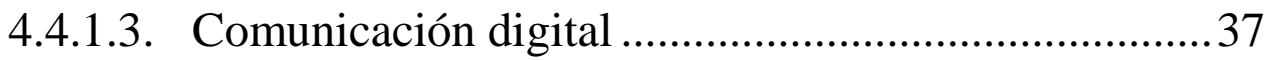

5. DISTRIBUCIÓN DE RECURSOS ................................................41

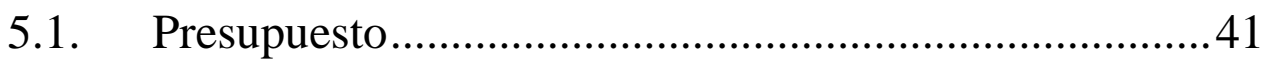

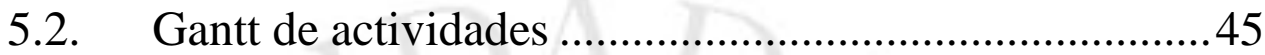

6. CONCLUSIONES Y RECOMENDACIONES..............................48

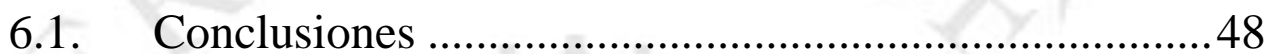

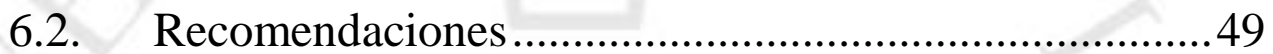

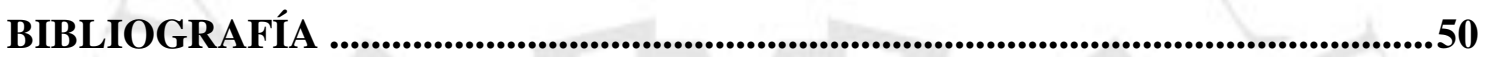

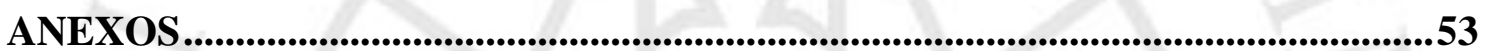




\section{RESUMEN}

Quntu Perú será lanzada al mercado peruano y en el presente trabajo se propone una estrategia de publicidad y marketing para la campaña de lanzamiento oficial. Para la esencia de chicha morada representada por este nombre, se realizó primero una investigación que permita conocer el comportamiento actual de consumidor y de la competencia sobre este tipo de bebidas naturales. Posteriormente, un estudio de mercado al público objetivo para validar el nuevo producto.

El valor tradicional de una chicha morada hecha en casa, resguarda valores como una bebida natural, saludable, deliciosa y fresca. Con los precedentes encontrados, se identificó fácilmente el mensaje que iría en los medios que permitirá influir en la compra final, además de las preferencias encontradas respecto a la presentación del producto. 


\section{INTRODUCCIÓN}

En el presente trabajo se realiza una campaña de lanzamiento de un nuevo concentrado de chicha morada $100 \%$ natural que será denominado como Quntu.

La característica principal de este producto es su sabor auténtico a chicha morada en concentrado listo para diluir, lo que evita el tedioso proceso de elaboración del refresco. Teniendo como ingrediente principal el maíz morado, membrillo, piña, limón y especias como clavo y canela, asegura resguardar el gusto de una bebida peruana como hecha en casa.

El proyecto abarca desde la investigación del escenario actual donde sería lanzado Quntu. Por lo que acudir a referencias teóricas y estadísticas servirá de guía para elección de su nombre, el packaging, la estrategia del mix de medios y el concepto creativo del producto, de forma que cumpla con los objetivos trazados.

El interés de tomar referencias actuales y contrastarlas con investigación de primera mano, yace por la necesidad de conocer el comportamiento de consumidor actual, específicamente del público objetivo. De aquellos descubriremos cómo piensan a la hora de comprar, sus gustos y hasta cómo ocupan su tiempo. Adicionalmente, en el ámbito profesional, versó el interés por conocer el contexto familiar y social del segmento propuesto como una variable, pues presenta condiciones alternas e intrafamiliares en dichos sujetos que influyen en sus decisiones.

Por otro lado, se realizó breves entrevistas a potenciales consumidores del concentrado de chicha morada para tomar insights que colaboren con la conceptualización del producto. En la conversación no se tuvo un número definido de preguntas y se basó más bien a una serie de etapas en la adquisición de un producto nuevo.

Finalizada la investigación, se podrá apreciar el despliegue de la campaña de lanzamiento. Iniciando con una breve presentación de los objetivos, el reason why del concepto del producto y cómo se materializa a través de sus distintas piezas gráficas publicitarias. 


\section{ANTECEDENTES DEL TRABAJO}

\subsection{Descripción del producto}

Quntu es el concentrado de chicha morada lanzado al mercado por importante empresa peruana. Su composición parte de una receta tradicional, teniendo como ingrediente principal el maíz morado, añadiendo el membrillo, piña, limón y por su puesto toques de canela y clavo de olor.

Este concentrado natural viene en una presentación de botella de vidrio por 500 mililitros y debe diluirse hasta en 2.5 litros de agua previamente hervida. Podrá ser encontrado en tiendas de autoservicio (Wong, Vivanda, Plaza Vea y Metro) y sus plataformas de e-commerce; además de bodegas en distintos distritos de Lima en el que resida nuestro target (La Molina, Surco, Miraflores, Pueblo Libre, San Miguel, Magdalena, entre otros) y serán expuestos en visicoolers.

A diferencia de otros productos, su auténtico sabor parte del cuidadoso proceso de preparación en el que no incluyen preservantes ni saborizantes. El producto no tiene azúcar añadida, siendo $100 \%$ natural. Debido a esto, conserva los valores esenciales del maíz morado reconocidos mundialmente como un super alimento (Perú, 2019).

\subsection{Análisis de la situación}

Pese a que el producto en discusión tiene virtudes propias de sus insumos, es necesario analizar el entorno en el que será lanzado, pues la competitividad del producto ya no es suficiente en sí misma si antes no se conoce en profundidad al cliente y dónde se desenvuelve (Pérez \& Ubago, 2006).

\subsubsection{Situación actual del Mercado}

De acuerdo a lo mencionado, es necesario conocer el macroentorno peruano respecto a la tipología de "mercado de consumo" que se relaciona al tipo de producto que se ofrecerá.

\section{a) Entorno político}

En el 2018, el Estado peruano a través del Ministerio de Salud decretó Ley de Promoción de la Alimentación Saludable para Niños, Niñas y Adolescentes. Según expuso el diario El Comercio, los fabricantes de alimentos procesados y empaquetados deberán usar obligatoriamente un etiquetado de advertencia denominado "Octógono". (El Comercio, 2019). Podrán colocar hasta 4 advertencias del contenido. Por ejemplo: alto en sodio, alto en azúcar, etc., haciendo que sea el consumidor el responsable y decisor de comprarlo o no. De acuerdo con esto, la Ley N. ${ }^{\circ} 30021$ encontró como "facilitador" el uso de advertencias o indicaciones del valor nutritivo en la cara frontal de la etiqueta del producto para la toma de decisiones. (El Peruano, 2018, pág. 59).

Gracias a esta nueva ley, se redefine y aprueba como alimento natural aquellos que son "mínimamente procesados, también incluyen combinaciones de dos o más alimentos sin procesar 
o mínimamente procesados, alimentos mínimamente procesados con vitaminas y minerales añadidos para restablecer el contenido original de micronutrientes o para fines de salud pública y alimentos mínimamente procesados con aditivos para preservar sus propiedades originales, como antioxidantes y estabilizadores." (El Peruano, 2018). Este factor es sumamente beneficioso para el tipo de producto que se piensa lanzar.

Adicionalmente, según indica en Instituto Nacional de Salud, la categoría de bebidas con o sin alcohol de categoría $\mathrm{H}$, específicamente en "chicha de maíz morado con azúcar", no contiene grasas trans ni otros componentes detectados como dañinos de acuerdo a la Ley de alimentación saludable. (Instituto Nacional de Salud, 2009, pág. 44).

\section{b) Entorno económico}

Una nota publicada por Gestión indica que en abril del 2019, siete grandes grupos de consumo presentaron aumento de precios: Alimentos y Bebidas (0.35\%); Transportes y Comunicaciones $(0.27 \%)$; Otros Bienes y Servicios (0.13\%); y, Cuidados y Conservación de la Salud $(0.13 \%)$ (Gestión, 2019).

De acuerdo al reporte presentado por SUNAT y expuesto por la CCL, durante la etapa de verano 2019 aumentó la importación y consumo de bebidas no alcohólicas de consumo directo creció respecto a la misma temporada del 2018. "Los jugos y néctares, con una participación del 16,9\% e importaciones que bordean los 893 mil litros. El $85 \%$ son concentrados de frutas en distintas presentaciones (...) En tanto, la importación de gaseosas cayó en $24 \%$ con respecto al verano del 2018" Además, las bebidas nutricionales "aumentaron sus compras en $8 \%$ y representan el 10\% del total importado (376 mil litros)." (Cámara de Comercio de Lima, 2019).

Las preferencias del consumidor han variado de acuerdo a su posición económica y social. Es ahora que los grupos sociales como individuos tienen tendencias de consumo por alimentos y bebidas saludables. En relación a la creciente alerta por bebidas con altos niveles de insumos no saludables, el público busca encontrar fácilmente aquello que no lo perjudica, rechazando en su mayoría de veces productos con altos niveles de azúcar.

Según Kantar Worldpanel, el empoderamiento femenino y el consumo saludable son claves para el comportamiento de consumo en los hogares de Lima Moderna. Al encontrar que el optimismo va en ascenso, hay una actitud positiva frente al pago de precios incrementados por productos mejorados y beneficiosos. Sin embargo, esto va acompañado del agitado estilo de vida de los decisores de compra, principalmente los que forman parte del público objetivo del presente trabajo. Indica este estudio que, frente a los labores diarios, la compra frecuente ha disminuido y se opta por compras por necesidad de abastecimiento, ascendiendo este último de $50 \%$ a $71 \%$. (La República, 2018). 


\section{c) Entorno social}

De acuerdo a lo mencionado en el apartado económico, podemos revelar que existe una creciente tendencia por el consumo saludable, eco-amigable, sostenible. Además, las políticas de alimentación saludable, a la vez que obligan a las empresas revelar el origen nutricional de sus productos, colaboran con una intención propia del individuo en comprar productos que contribuyan con el conocimiento de lo que está ingiriendo. De acuerdo a la Kantar Wordlpanel, “el $87 \%$ de hogares peruanos piden a los fabricantes que desarrollen productos más nutritivos; frente al $53 \%$ que requiere productos más económicos; el $21 \%$ que pide productos más prácticos; y el 11\% mayor variedad en colores, sabores y aromas" (Kantar World Panel, 2019)

El informe presentado en Perú-Retail detalla, además, que hay otras 5 tendencias del comportamiento del consumidor en el ámbito social. Empezando por una preocupación por el futuro amigable y sostenible, menciona que las marcas que son responsables con el planeta son las favoritas por lo consumidores, pues incluyen desde sus insumos hasta su presentación componentes orgánicos. (Peru Retail, 2018)

Por otro lado, la demanda por el control y transparencia de lo que consumen va de la mano con la nueva Ley $\mathrm{N}^{\circ} 30021$ de alimentación saludable. Se ha convertido un hábito revisar el nivel de nutrientes que contiene cada empaque, pero la dificultad de su lectura será mejorada con los octógonos, haciendo que el peruano sea un consumidor consciente. (Wolf, 2017)

En relación con la referencia anterior, la tercera tendencia sería el ahorro de tiempo como consecuencia de su agitado estilo de vida, pues "muchos consumidores optan por alimentos de preparación rápida (...) buscando soluciones sencillas, pero que aporten una nutrición adecuada" (Peru Retail, 2018). Además de la cercanía, que para las amas de casa es imprescindible encontrar productos frescos con promociones atractivas o con precios bajos sin promoción.

Como cuarta y quinta tendencia de consumo por el mercado, el apoyo por consumir productos peruanos y negocios locales es una forma de expresar el sentimiento de peruanidad y crecimiento económico del país. También consideran aquellas empresas que son respaldadas por productores nacionales. Por último, la necesidad de generar experiencias positivas con el producto se convierte en parte de journey del consumidor.

\section{d) Entorno tecnológico / innovador}

El Instituto Nacional de Salud, brinda al público en general la aplicación "Tablas Peruanas de Composición de Alimentos - TPCA". Esta app tiene como objetivo brindar información inmediata sobre la composición de alimentos. Añaden que se podrá observar el valor referencial de preparaciones típicamente consumidas según niveles socioeconómicos (Instituo Nacional de Salud, 2019). Como esta aplicación, existen otras en las tiendas de Android y Apple que permiten 
medir el consumo de calorías por porción, ejercicios adecuados para los objetivos que se estén buscando, recetas y alimentación recomendada; sin embargo, no tiene un apoyo médico y como tal son recomendables solo para personas que adicionalmente se encuentren asesoradas por un especialista.

En un artículo a Gestión en el 2017 publicado por INEI, Max Vidal aporta al estudio sobre las amas de casa, que su exposición al entorno respecto a aspectos económicos, políticos, sociales, es mayor por "necesidad y decisión propia". Muy aparte de poder conseguir una actividad laboral, se involucran en actividades sociales por el poder de información que les ha brindado internet. Ahora toman una actitud más "perspicaz" (Vidal, 2017).

Para las mujeres que cumplen un doble rol, internet no deja de ser una fuente de información relevante respecto al consumo de televisión. Pues ahora, ellas "reciben ofertas y promociones por este medio (web, YouTube, redes sociales)", siendo más del 50\% de amas de casa las que navegan (Correo, 2018).

Asimismo, Ipsos menciona que si bien el shopper peruano "continúa comprando en tiendas, una importante proporción investiga en internet antes de efectuar su compra. Igualmente, cerca del $59 \%$ que compra en la web, mira el producto en una tienda (física) antes de hacerlo" (IPSOS, 2017).

También basado en internet, existe el uso de aplicaciones de delivery. Estas aplicaciones permiten introducir una tarjeta, realizar selección de productos en autoservicios que estén cercanos a la zona donde se encuentre el comprador.

\subsubsection{Situación actual de la industria}

Se realizará un análisis previo del microentorno, específicamente de la industria y el comportamiento de la competencia frente a distintos factores que se desarrollan en el campo, además de la importancia de los actores involucrados en su desarrollo.

\section{a) La negociación con el consumidor}

El Congreso Anual de Marketing (CAMP) coincidió a través de sus expositores que "la clienta moderna apostará por una oferta más saludable (con bebidas y alimentos que pueden costar más pero le aseguren bienestar y salud). Los productos con este tipo de características pueden costar hasta 3 veces más que uno regular, sin embargo, esto no disminuirá el consumo masivo de bebidas tradicionales." (Correo, 2018). Es decir, el público objetivo podría apostar por un producto que le presenta mayores beneficios a un precio elevado, siempre y cuando resguarde los valores nutricionales que indica. Para ello, seguramente habrá estado previamente informada, tanto con profesionales como con referencias digitales y su entorno social. 
Asimismo, para hacerse atractivo ante un mercado tan informado, la consumidora en general valora que estén los "productos o marcas que buscan (54\%) como principal factor; seguido por personal amable y dispuesto a ayudar (53\%), promociones atractivas (53\%), tiene los productos más frescos (35\%), y tiene los precios más bajos sin promoción (33\%).o, es necesario que los retailers ofrezcan" (La República, 2018). Estos factores permitirán introducir al consumidor en una experiencia que ayude a influir en la compra con mayor facilidad.

\section{b) Competencia directa y productos sustitutos}

Una referencia que puede ayudar al entendimiento del nivel de consumo de las bebidas que no contienen alcohol, es el estudio de importación de agua embotellada realizada por la Cámara de Comercio. En él se menciona que la importación de jugos y néctares se encuentra en un cuarto lugar con una participación del 16.9\% en el total de importaciones. Los concentrados de frutas son los favoritos. Además, las bebidas nutricionales está en quinto lugar frente a las demás. Esto representa el $10 \%$ del total y es el insumo de aloe vera que está abarcado su totalidad con un $89 \%$ de participación. (Cámara de Comercio de Lima, 2019)

Algunos productos sustitutos, se encuentra la gaseosa o bebidas gasificadas que ha disminuido en un $24 \%$ respecto al año anterior; esto debido a la tendencia del consumo por lo natural y al temor de los altos niveles de azúcar que pueden provocar enfermedades. Sin embargo, no dejan de ser emblemáticas y favoritas bebidas como Coca-Cola, Inca Kola, Kola Real y Pepsi.

Cabe resaltar que el posicionamiento en la mente del consumidor de las gaseosas lleva un largo tiempo y una gran inversión en publicidad. Por otro lado, las bebidas concentradas para diluir presentan un bajo nivel de exposición, habiendo una tendencia de las mismas marcas por mostrar productos que son listos para beber, pero que tienen menos valor nutricional.

\section{c) Rivalidad entre competidores - benchmark}

Finalmente, se puede analizar los estándares competitivos de los productos que se relacionan como Quntu. A continuación se ofrecerá un análisis sintetizado de los factores que más importan para el presente estudio de al menos 3 competencias por categorías:

\section{Competencia directa: concentrados por preparar}

\begin{tabular}{|l|l|l|l|}
\hline Factor a evaluar & Naturale & Sayani & Cosecha de oro \\
\hline Presentación & & & \\
& & &
\end{tabular}




\begin{tabular}{|c|c|c|c|}
\hline Packaging & $\begin{array}{l}\text { Botella plástico } \\
\text { Etiqueta adhesiva } \\
\text { Insumos en etiqueta } \\
\text { Incluye rendimiento }\end{array}$ & $\begin{array}{l}\text { Botella plástico } \\
\text { Etiqueta adhesiva } \\
\text { Insumos en etiqueta } \\
\text { Incluye rendimiento }\end{array}$ & $\begin{array}{l}\text { Bolsa plástico } \\
\text { Descripción en etiqueta } \\
\text { Sin figura de insumos } \\
\text { Incluye rendimiento }\end{array}$ \\
\hline Rendimiento & Hasta 6 litros & Desde $1.21 \mathrm{t}$ hasta $301 \mathrm{tt}$ & Hasta $2.51 \mathrm{t}$ \\
\hline Precio & S/ 16.90 & S/ 12.90 & S/ 5.99 \\
\hline Producto & $\begin{array}{l}\text { - Contiene azúcar } \\
\text { - Agua tratada } \\
\text { - Ácido cítrico } \\
\text { - Ácido Sórbico }\end{array}$ & $\begin{array}{l}\text { - Agua tratada } \\
\text { - Contiene azúcar } \\
\text {-Aditivos alimentarios } \\
\text { permitidos }\end{array}$ & $\begin{array}{l}\text { - Contiene azúcar } \\
\text { - Ácido Cítrico } \\
\text { - Benzoato de sodio }\end{array}$ \\
\hline Plaza & $\begin{array}{l}\text { Mayor presencia de } \\
\text { productos listos para } \\
\text { beber. } \\
\text { Estrategia HORECA. }\end{array}$ & $\begin{array}{l}\text { Mayor distribución por } \\
\text { maquila. Algunas } \\
\text { bodegas en Perú, por } \\
\text { contacto. } \\
\text { Estrategia HORECA. }\end{array}$ & $\begin{array}{l}\text { Mayor distribución por } \\
\text { maquila o producción } \\
\text { contratada. } \\
\text { Estrategia HORECA. }\end{array}$ \\
\hline Promoción digital & $\begin{array}{l}\text { - Web propia } \\
\text { - Mensaje en redes (FB } \\
\text { e IG)*: refréscate, sin } \\
\text { azúcar añadida, } \\
\text { sustituto de agua, bajo } \\
\text { en calorías, pura fruta. }\end{array}$ & $\begin{array}{l}\text { - Web propia } \\
\text { - Mensajes en redes } \\
\text { (FB): puntos de } \\
\text { distribución, invitación } \\
\text { a los negocios, } \\
\text { beneficios r y } \\
\text { propiedades, } \\
\text { instantáneo. }\end{array}$ & $\begin{array}{l}\text { - Web propia } \\
\text { - Mensajes en redes } \\
\text { (FB): bebidas listas } \\
\text { para beber. No hay } \\
\text { muchos posts. }\end{array}$ \\
\hline $\begin{array}{l}\text { Promoción BTL y } \\
\text { alianzas comerciales }\end{array}$ & $\begin{array}{l}\text { - Naturale realiza } \\
\text { activaciones en centros } \\
\text { comerciales y de } \\
\text { trabajo. } \\
\text { - Participan en eventos } \\
\text { como ferias. } \\
\text { - Tiene alianzas con } \\
\text { supermercados y } \\
\text { tiendas de autoservicio. }\end{array}$ & $\begin{array}{l}\text { - Los mismos } \\
\text { distribuidores quienes } \\
\text { se encargan de } \\
\text { personificar la marca. } \\
\text { - Participan en eventos } \\
\text { como ferias. }\end{array}$ & $\begin{array}{l}\text { - Participan en eventos } \\
\text { como ferias. }\end{array}$ \\
\hline
\end{tabular}

Tabla 1: comparativo de las $4 P$ de marketing de concentrados de chicha morada disponibles en el mercado peruano.

Elaboración propia. Distintas fuentes.

\section{Competencia indirecta: listas para beber sabor chicha}

Factor a evaluar

Naturale

Gloria

Selva 


\begin{tabular}{|c|c|c|c|}
\hline Presentación & & 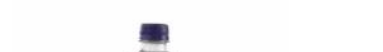 & - \\
\hline Packaging & $\begin{array}{l}\text { - Botella plástico } \\
\text { - Textura de granos } \\
\text { - Etiqueta adhesiva }\end{array}$ & $\begin{array}{l}\text { - Botella plástico } \\
\text { - Presentación clásica } \\
\text { de Gloria } \\
\text { - Etiqueta adhesiva }\end{array}$ & $\begin{array}{l}\text { - Botella vidrio } \\
\text { - Etiqueta serigrafía } \\
\text { - Insumos en etiqueta }\end{array}$ \\
\hline Cantidad & $1 \mathrm{lt}$ & $1.51 \mathrm{t}$ & $900 \mathrm{ml}$ \\
\hline Precio & S/ 5.5 & S/ 4.75 & S/ 6.9 \\
\hline Producto & $\begin{array}{l}\text { - Sin saborizante } \\
\text { - Con azúcar en niveles } \\
\text { bajos }\end{array}$ & $\begin{array}{l}\text { - Contiene lácteos, } \\
\text { gluten y soya. } \\
\text { - Contiene vitamina C. } \\
\text { - Contiene azúcar y } \\
\text { saborizantes }\end{array}$ & $\begin{array}{l}\text { - Contiene lácteos y } \\
\text { soya. } \\
\text { - Contiene vitamina C. } \\
\text { - Contiene azúcar y } \\
\text { saborizantes }\end{array}$ \\
\hline Plaza & $\begin{array}{l}\text { Principales super } \\
\text { mercados y tiendas por } \\
\text { conveniencia. }\end{array}$ & $\begin{array}{l}\text { Principales super } \\
\text { mercados y tiendas por } \\
\text { conveniencia }\end{array}$ & $\begin{array}{l}\text { Principales super } \\
\text { mercados y tiendas por } \\
\text { conveniencia }\end{array}$ \\
\hline Promoción & $\begin{array}{l}\text { Son el foco en las } \\
\text { comunicaciones. }\end{array}$ & $\begin{array}{l}\text { Escueto apartado en } \\
\text { web. } \\
\text { Último post de chicha } \\
\text { en el } 2017 .\end{array}$ & $\begin{array}{l}\text { Web no visualizable. } \\
\text { Asociación de chicha } \\
\text { con frescura y } \\
\text { complemento, además } \\
\text { de peruanidad. }\end{array}$ \\
\hline
\end{tabular}

Tabla 2: comparativo de las $4 P$ de marketing de bebidas hechas a base de chicha morada disponibles en el mercado peruano.

Elaboración propia. Fuente Plaza Vea 2019

\section{Competencia de sustitutos: bebidas nutritivas}

\begin{tabular}{|c|c|c|c|}
\hline Factores a evaluar & Valores añadidos & Cold pressed & Base Aloe vera \\
\hline Presentación & $\Rightarrow$ & & \\
\hline Packaging & $\begin{array}{l}\text { - Botella de vidrio } \\
\text { - Etiqueta incluye } \\
\text { ingredientes } \\
\text { beneficios }\end{array}$ & $\begin{array}{l}\text { - Botella de plástico } \\
\text { - Etiqueta incluye } \\
\text { ingredientes } \\
\text { - Incluye beneficios } \\
\text { coldpressed }\end{array}$ & $\begin{array}{l}\text { - Botella de vidrio } \\
\text { - Etiqueta incluye } \\
\text { beneficios aloe vera e } \\
\text { ingredientes }\end{array}$ \\
\hline
\end{tabular}




\begin{tabular}{|c|c|c|c|}
\hline Cantidad & $300 \mathrm{ml}$ & $500 \mathrm{ml}$ & $450 \mathrm{ml}$ \\
\hline Precio & S/ 6.90 & S/ 15.00 & S/ 2.90 \\
\hline Producto & $\begin{array}{l}\text { - Endulzado con stevia } \\
\text { - Contiene chía } \\
\text {-Antioxidante, } \\
\text { minerales, hidratación, } \\
\text { omega 3, proteínas, } \\
\text { vitaminas. }\end{array}$ & $\begin{array}{lr}\text { - Extracto prensado en } \\
\text { frío } & \\
-\quad 100 \% & \text { Producto } \\
\text { natural } & \\
-\quad \text { Libre de } & \text { lactosa y } \\
\text { gluten } & \\
-\quad \text { No } & \text { contiene } \\
\text { endulzantes } & \text { ni } \\
\text { conservantes } & \end{array}$ & $\begin{array}{l}\text { - Alto contenido de } \\
\text { vitamina C, fuente de } \\
\text { vitamina A y vitamina } \\
\text { E. } \\
\text { - Jugo de aloe vera } \\
\text { - Anti-inflamatorios y } \\
\text { contribuye a la firmeza } \\
\text { de la piel }\end{array}$ \\
\hline Plaza & $\begin{array}{l}\text { Principales } \\
\text { supermercados }\end{array}$ & $\begin{array}{l}\text { Principales } \\
\text { supermercados y } \\
\text { bodegas }\end{array}$ & $\begin{array}{l}\text { Principales } \\
\text { supermercados } \\
\text { bodegas }\end{array}$ \\
\hline Promoción & $\begin{array}{l}\text { - Presencia en ferias } \\
\text { - Activaciones } \\
\text { - Baja interacción en - } \\
\text { redes sociales }\end{array}$ & $\begin{array}{l}\text { Alto nivel de } \\
\text { interacción en redes }\end{array}$ & $\begin{array}{l}\text { - Alto nivel de } \\
\text { interacción en redes } \\
\text { - Publicidad en BTL y } \\
\text { ATL }\end{array}$ \\
\hline
\end{tabular}

Tabla 3: comparativo de las 4P de marketing de bebidas no gasificadas no alcohólicas, que son nutritivas.

\section{Elaboración propia. Fuente Wong 2019}

Como resultado del análisis, se puede observar que los concentrados no tienen mucha visibilidad en el mercado, se venden más bien sobre una estrategia de HORACE; sin embargo, el producto que se lanzará sí desea llegar al consumidor final, especialmente amas de casa.

Los derivados de chichas son más comerciales, pero no tienen una particularidad como producto de chicha morada. Su presentación varía, lo que refleja que eso y el precio destinan el producto a un segmento específico del mercado, posiblemente A y B.

Finalmente, las bebidas nutritivas están en el boom de la industria. Las personas que se cuidan y cuidan a sus hijos creen en los beneficios.

Por ello, el nuevo concentrado de chicha tendrá mayor exposición que su competencia directa, con una comunicación y presentación minimalista y sofisticada, además de femenina, y resaltando los grandes beneficios de los frutos con los que está compuesta esta receta tradicional. Esta será finalmente la estrategia de Quntu. 


\section{EL PÚBLICO OBJETIVO}

\subsection{Las amas de casa modernas}

El público objetivo son amas de casa de nivel socio-económico A, B y C, que oscilan entre los 28 y 45 años de edad y se caracterizan por ser modernas y prácticas. Ellas relacionan lo natural con saludable y lo toman muy en cuenta, sobre todo en la alimentación de sus hijos.

Las amas de casa modernas valoran el sabor real de una bebida, especialmente la chicha morada que es un refresco peruano y tradicional. Sin embargo, la mayoría no tienen tiempo de prepararlo, pues su procedimiento es tedioso y extenso en cuestión de tiempo. Además, la mayoría no conocen todos los beneficios para la salud que tiene el maíz morado, ingrediente principal de este concentrado, pero sí valoran un producto natural y que no tenga componentes artificiales perjudicando la salud de sus hijos.

\subsection{Comportamiento del público objetivo}

Según el Centro de Especialización Digital Mott, las amas de casa de hoy en día ya no tienen las mismas características o cualidades que antes, pues se han adaptado a la era digital en la que nos encontramos por lo que han podido modernizarse. (Mott, 2019)

Según Ipsos y su informe sobre las amas de casa, el número estimado de mujeres que desempeñan este rol es de 8 millones. De ellas, 6 millones son amas de casa principales y 2 millones cumplen un rol de apoyo secundario en las funciones del hogar. (IPSOS, 2018)

El $24 \%$ de ellas ha terminado los estudios de educación superior y el $71 \%$ quiere seguir estudiando. Además, el $48 \%$ se dedica, exclusivamente, al cuidado del hogar, el 51\% trabaja eventual o permanentemente y el $58 \%$ de las que trabajan desearían dejar de hacerlo.

Según en Instituto Nacional de Estadística e Informática (INEI), el 32 2\% de las madres de nuestro país son amas de casa y el $42.8 \%$ de mamás tienen entre 30 y 49 años. (INEI, 2017)

Por otro lado, según las estadísticas de Ipsos, el 90\% de las amas de casa tiene hijos por los que se preocupan por su buena alimentación y su salud. Incluso el $29 \%$ de ellas suele pasar tiempo con sus pequeños como forma de entretenimiento; es decir, los llevan al parque o juegan con ellos. Otra forma de ocupar el tiempo libre es mirando programas de televisión, el 27\% de este sector lo hace con gran frecuencia y con un promedio de 3 a 4 horas al día según el informe medios Tradicionales hábitos y actitudes en Lima metropolitana (IPSOS, 2017). Por otro lado, el $13 \%$ practica deporte como correr o asiste al gimnasio y el $11 \%$ realizan actividades sociales como visitar a un familiar, ir a misa o reunirse con amigos.

En relación con sus hábitos de consumo, según Ipsos, el 74\% de amas de casa decide qué comprar en el instante; es decir, muy pocas llevan una lista de compras. El lugar al que se dirigen a comprar son las bodegas y mercados por su familiaridad con los vendedores y por sus bajos precios, pero 
también lo hacen en supermercados por las ofertas y la sensación de modernidad, les genera seguridad. Por otro lado, tienen mayor motivación por comer saludable y por valorar lo natural. incluso las amas de casa se han vuelto más selectivas, pues cuentan con amplia diversidad de productos y tiene mayor acceso a la información a la hora de comprar. Ya no deciden por un precio más bajo, sino que han sabido rescatar la calidad del producto.

El informe de clasificación por estilo de vida de Arellano Marketing, detalla que les interesa los productos prácticos, es decir, que no sean muy tediosos de ser preparados, de esta forma evitan sentirse solo amas de casa. (Arellano Marketing, 2019)

Con respecto a los medios de comunicación que consumen, el 75\% de amas de casa miran televisión posicionándolo en el primer lugar en comparación a otras plataformas. Según Ipsos, las amas de casa tienen preferencia por ver, en primer lugar, noticieros, luego películas, en tercer lugar novelas y en cuarto programas de espectáculo. Además, se determinó que los horarios en los que suelen ver más televisión son en las tardes y noches. (IPSOS, 2018)

Según el portal Kantar IBOPE media, las mujeres peruanas son "multipantalla"; es decir, consumen medios de una forma más variada. El $44 \%$ utilizan las redes sociales para comunicarse e interactuar con amigos y familiares, y el 19\% comentaron que mientras ven televisión hacen búsquedas en internet sobre los productos que vieron ser anunciados por la gran pantalla. (Kantar Ibope Media, 2018)

Es así que el internet se posiciona en segundo lugar como medio de comunicación más consumido por las amas de casa. Para ser más específicos, en el nivel socioeconómico A se encuentra el $42 \%$ de ellas en el NSE B el 35\% y en el NSE C el 22\%. (IPSOS, 2017)

Según Ipsos, el 45\% de las amas de casa poseen una cuenta en alguna red social y las mujeres del sector socioeconómico A son las que tienen más de una cuenta creada. La frecuencia con la que utilizan las redes sociales ya sea en casa o en cualquier otro lugar es alta, pues el $37 \%$ lo utilizan todos los días. Por otro lado, el $90 \%$ no compraría productos por internet.

La radio es otro de los medios que utilizan las amas de casa, pero solo un 18\%. Según el informe "Medios Tradicionales, hábitos y actitudes en Lima metropolitana" de (Lima Consulting, 2018), los motivos principales para escuchar radio son "relajarse" y "entretenerse". Suelen escuchar principalmente en la mañana y hasta el final de la tarde. Incluso el lugar donde se escucha con mayor frecuencia es en el hogar.

Otro de los datos resaltantes es que el $81 \%$ de las amas de casa piensa que la publicidad sí influye en el momento de la compra y que las promociones le llaman mucho la atención. El 54\% prefieren comprar dos productos por uno, el $32 \%$ escogen los vales de compra y el $28 \%$ prioriza los cierra puertas. 
Según Ipsos, el 90\% de las amas de casa se considera exitosa y cuando preguntaron qué significa el éxito para ellas el 30\% respondió que "sacar a su familia adelante" era parte del progreso, el $22 \%$ respondió "tener un negocio propio" y el $21 \%$ "Tener a mi familia feliz". (IPSOS, 2017)

\subsection{Buyer personas}

Las consumidoras de Quntu, concentrado de chicha morada, son amas de casa que compran productos que ellas y sus familias consuman, pero que sean naturales, beneficiosos para la salud y que sean rápidos de preparar.

Se encontró cuatro buyer personas basados en la investigación del público objetivo y por perfil de consumidores de productos Eco y Bio (AECOC, 2019)

- Las amas de casa modernas que llevan un estilo de vida saludable: se preocupan al 100\% en la nutrición y salud de su familia, están pendientes de los componentes y nutrientes que contiene el producto final.

- Las amas de casa modernas que compran productos naturales por tendencia: solo les basta saber que es un producto natural y que ayudará a cuidar la salud.

- Las amas de casa modernas que compran productos naturales por el sabor superior: les preocupa que sea cero artificial y la frescura que pueda ofrecerles porque lo consideran más "gourmet".

- Las amas de casa modernas que relacionan los natural con la nostalgia: antiguamente no se utilizaban ningún producto artificial para cocinar.

De estos cuatro perfiles y de acuerdo al brief, el presente proyecto se centrará en dos: amas de casa modernas con un estilo de vida saludable y las que compran productos naturales por tendencia.

\section{a) Patricia - 42 años - Profesora de nido - Salario mensual S/ 1300.}

Convive con su esposo en un departamento propio en San Borja, ambos trabajan. Tienen dos hijos, uno de 12 años y otra de 9. Su familia es muy importante para ella y siempre trata de que sus hijos crezcan saludables.

Trabaja en un nido como profesora de 8 de la mañana a 1 de la tarde. Le han propuesto horas extra, pero ella no desea, porque le gusta tener tiempo libre para realizar diferentes actividades y estar siempre presente para su familia. Además, considera que no lo necesita todavía.

Patricia es de las amas de casa que están pendientes de los alimentos que consume su familia, se preocupa mucho por la salud de sus hijos, pues quiere que crezcan sanos y espera que no contraigan ninguna enfermedad. Conoce muy bien qué productos comprar y qué descartar por completo. Le gusta mucho meterse a internet a leer sobre los nutrientes componentes o valores 
que poseen los alimentos. Eso sí, no le gusta pasar mucho tiempo en la cocina, porque considera que no es lo suyo. Va al supermercado una vez a la semana y cuando lo hace se puede pasar unas cuantas horas porque le gusta ver con cuidado los cuadros nutricionales de los productos y siempre compra insumos $100 \%$ naturales.

Es una mamá activa, siempre propone algo para hacer como salir a jugar al parque con sus hijos, ver una película con ellos, salir con sus amigas para conversar de la vida o a veces sale a correr de noche.

Patricia se encarga de preparar el desayuno, la lonchera de los niños y el almuerzo. Cuando lo hace, le gusta ver de reojo algún noticiero o programa de televisión. Normalmente en el desayuno les da de tomar un vaso de yogurt griego y un tazón de avena con frutos secos. En las loncheras le envía una fruta, cereal bajo en azúcar y prepara una bebida natural como jugo de naranja, jugo de maracuyá o chicha morada, pero termina renegando, porque son un poco tediosos en hacerlo y demandan mucho tiempo. A la hora del almuerzo, trata de realizar un plato con alguna proteína, legumbres y/o verduras acompañado de la bebida preparada en la mañana para la lonchera.

Patricia desearía que aparezca en el mercado algún concentrado $100 \%$ natural, sin saborizantes ni preservantes, ni azúcar, puesto que ella utiliza panela para endulzar las bebidas de sus hijos. Desconoce si en el mercado existe, ha buscado y ha llegado a encontrar concentrados de bebidas naturales, pero siempre contienen algún elemento que no lo considera sano.

\section{b) Danitza - 35 años - No trabaja, pero está pensando en hacerlo.}

Vive en la casa de su mamá en un departamento en Pueblo Libre. Tiene una hija de 7 años y no piensa en tener más hijos. Su ex esposo le da una mensualidad para los gastos de la pequeña. En la medida de lo posible, trata que su hija no consuma muchas golosinas o alimentos procesados, eso sí, nunca ha permitido que tome gaseosa, lo considera contraproducente para la salud en una niña tan pequeña. Siempre trata de darle otro tipo de bebidas y si es natural mejor.

Se levanta temprano y se queda mirando televisión un rato, le gusta ver noticias. Luego levanta a la niña y la deja colocándose el uniforme. Se va a la cocina y prepara el desayuno y la lonchera. Normalmente le da Yogurt con cereal y pan de molde con queso o mantequilla. En la lonchera suele llevar un pan de molde con palta o con queso, un bowl de frutas y algo para beber puede ser un jugo en caja o a veces preparar alguna bebida natural. Cuando regresa de dejar a su hija en el colegio prende la televisión y se queda viendo programas hasta la hora que tiene que recoger a la niña. Incluso, cuando cocina está pendiente de lo que emite la pantalla. Es una mamá activa en redes sociales, le gusta publicar y comentar estados de Facebook o sube historias a su Instagram. Es de las personas que mientras ve televisión puede estar en su celular o computadora. 
No le gusta demorarse mucho en la cocina, porque lo considera aburrido, por eso siempre trata de cocinar rápido y le gusta hacer platos criollos. Siempre acompaña el almuerzo de alguna bebida que no sea agua porque su hija no lo toma ya que no tiene sabor. Es de las personas que va una o dos veces al supermercado y cuando lo hace compra para todo el mes. Si algo le falta, va a su bodega de confianza. Se deja influenciar por las propagandas que ve con respecto a productos naturales, pues considera que eso está en tendencia.

Espera que salga al mercado algún concentrado de bebidas naturales para que su pequeña pueda beberlo sin ningún problema y darle cuantas veces desee. Sabe perfectamente que bebidas embotelladas o en cajas ya listas no pueden ser consumidas con frecuencia. 


\subsection{Journey del consumidor}

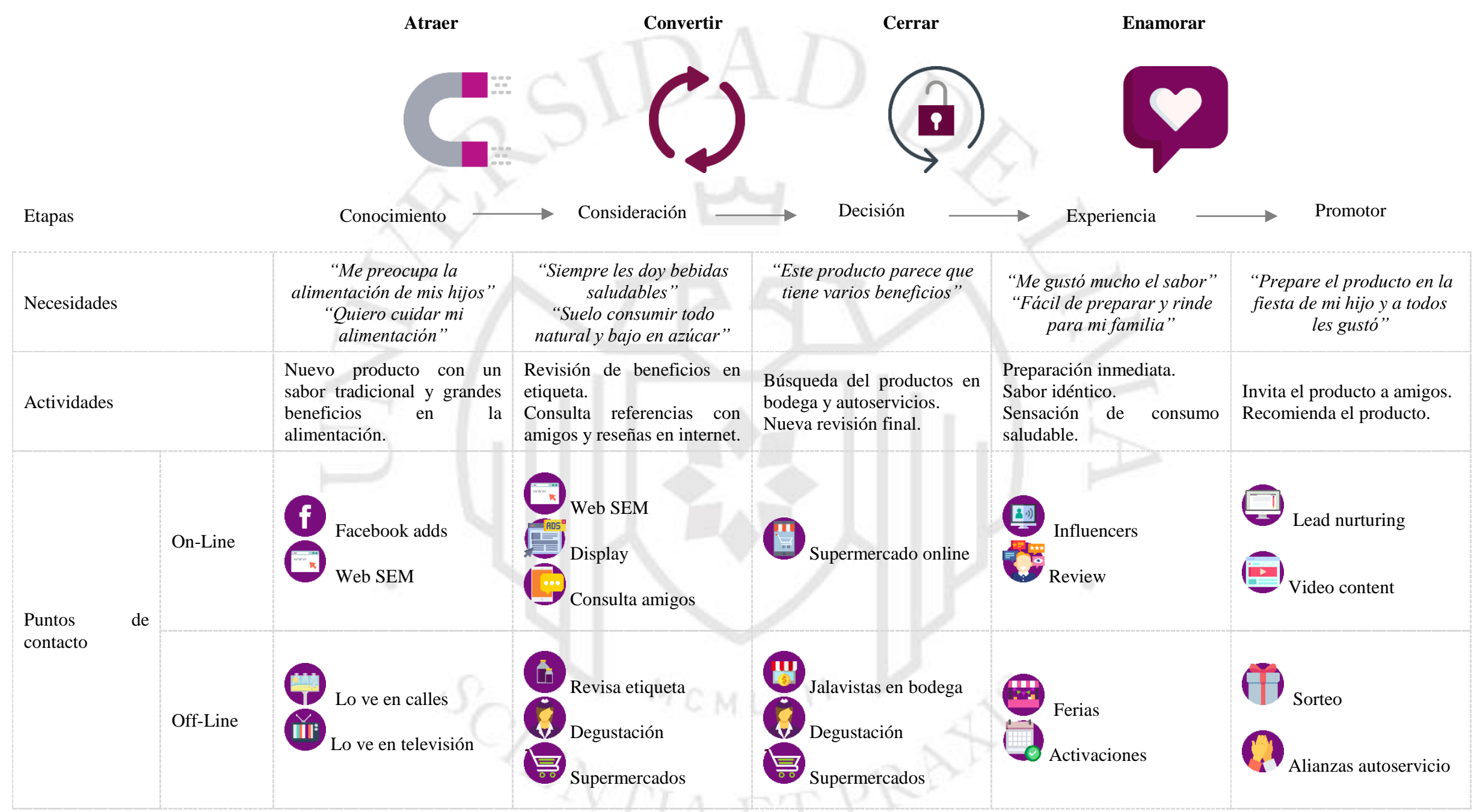

Tabla 4: Viaje del consumidor para adquirir un producto.

Elaboración propia. Fuente Focus Group y encuestas propias (Anexo 1). 


\section{Insights}

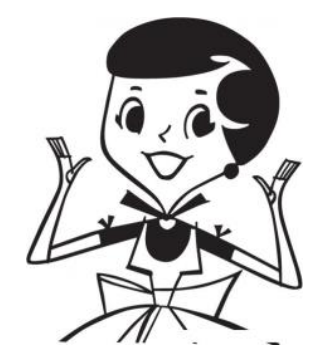

INNOVACIÓN

PODER

PROTECCIÓN

PRAGMÁTICO

\begin{tabular}{|c|l|c|c|}
\hline $\begin{array}{c}\text { A veces le mando } \\
\text { agua otro día } \\
\begin{array}{c}\text { limonada o yogurt } \\
\text { trato siempre de } \\
\text { variar para que no se } \\
\text { aburra" }\end{array}\end{array}$ & $\begin{array}{c}\text { "Decido comprar } \\
\text { siempre insumos } \\
\text { naturales y/u } \\
\text { orgánicos" }\end{array}$ & $\begin{array}{c}\text { "Trato de darle } \\
\text { refrescos naturales } \\
\text { porque es más } \\
\text { saludable" }\end{array}$ & $\begin{array}{c}\text { "No suelo preparar } \\
\text { bebidas naturales } \\
\text { demandan mucho } \\
\text { tiempo por eso le doy } \\
\text { agua, chocolatada o } \\
\text { yogurt" }\end{array}$ \\
\hline $\begin{array}{l}\text { No son rutinarias, les } \\
\text { gusta innovar en todo } \\
\text { sentido }\end{array}$ & $\begin{array}{l}\text { Líderes } \\
\text { conocimiento } \\
\text { información }\end{array}$ & $\begin{array}{l}\text { Bienestar de su su fomilia, compartir } \\
\text { con la familia }\end{array}$ & Son prácticas \\
\hline
\end{tabular}

Tabla 5: Características del público objetivo

Elaboración propia. Fuente Focus Group.

\section{PROPUESTA DE COMUNICACIÓN}

\subsection{La marca: concepto creativo}

El concepto creativo de producto, busca reflejar que Quntu es un concentrado 100\% natural basada en la auténtica receta tradicional de chicha morada y que contiene grandes beneficios para la salud.

Se plasmará en medios como la mejor opción en concentrados de cereales, frutas y bebidas nutritivas, pues se rescatará los beneficios que tiene consumirla, además de hacer hincapié en que es un producto sin preservantes, ni saborizantes, ni azúcar añadida y es rápido de preparar.

\subsection{Identidad de marca}

\section{a) Nombre}

Para la elección de este nombre, se rescataron las características del producto en relación a los sentidos; es decir, su sabor, su textura, su color y su olor. Es entonces que Quntu nace del quechua y significa "aroma” según el diccionario Runasimi. (runasimi, 2019)

Por otro lado, se escogió traducir "aroma" al idioma quechua, pues el maíz morado era un cereal cultivado por los Incas, incluso era un alimento sagrado para ellos. Se utilizaba como ofrenda y 
también era preparada como bebida. Los incas: la tomaban después de comer y antes de realizar arduos trabajos, pues les daba fortaleza y energía. Es por ello que se decidió conservar la importancia que le daban los antepasados y que sea vea reflejado en el nombre. Además, existe una tendencia del mercado peruano por consumir lo que los identifica como peruanos, siendo el quechua un idioma nativo del país.

\section{Quntu}

\section{Auténtica receta tradicional}

Para llegar al nombre, se realizó una lista de características del producto y preferencias del consumidor, donde quedaron tres nombres: Mi morena, +Zumo y Quntu. Para conocer lo que verdaderamente transmite el nombre, se realizó una encuesta online al público objetivo para conocer su favorito y por qué eligieron ese nombre. (Anexo 2)

Quntu fue el nombre escogido, pues consideran que es original, el cual es fácil de recordar. Además que llegan a relacionarlo con el producto final como la chicha morada.

\section{b) Logo}

Con el logo se busca transmitir autenticidad y originalidad, calidad, elegancia y verse como un producto $100 \%$ natural.

El logo tiene características particulares pues se basa en la tipografía Quesha, la cual será analizada más adelante; sin embargo, presenta cierta variación en la letra principal Q para darle elegancia y continuidad. Además, se decidió por colocar un punto o círculo dentro de la letra $\mathrm{Q}$ como símbolo de protección y con la finalidad de que colabore con el significado de concentrado y de mayor armonía al logo. Por otro lado, se puede distinguir tres hojas color verde por encima de las letra U y N esto con el fin de reflejar lo que envuelve al maíz: la panca. Como diseño final podemos observar que es armonioso, da vida y los colores se complementan muy bien.

Se decidió optar por un logotipo para conservar atributos como la elegancia, simplicidad y pureza. El resultado final es el siguiente; sin embargo, se verá más adelante como los apoyos, como packaging y artes publicitarios, colaboran con la conceptualización del producto.

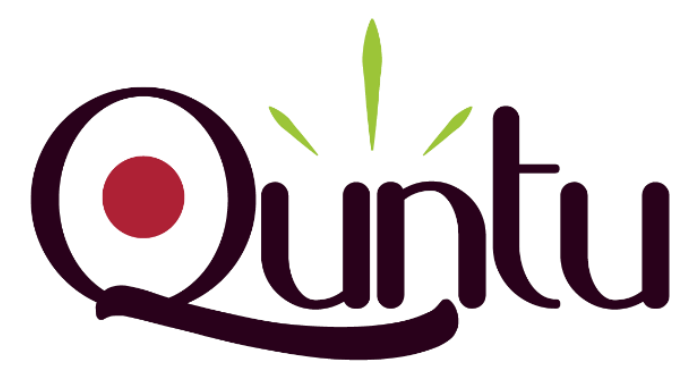




\section{c) Pantone}

Los colores escogidos están relacionado al ingrediente principal del producto. Se conservó el color morado, pues hace referencia al color del maíz morado; además, se añadió mínimamente el color verde para simular las hojas que acompaña a este cereal más conocido como panca. De esta forma refuerza la identidad de nuestro producto. Para añadir vida, se agregó un violeta en el centro de la $\mathrm{Q}$, simbolizando fortaleza, feminidad, realeza.

Estos colores contrastan con el blanco para darle mayor presencia elegancia y se puedan distinguir del fondo ya que el propio concentrado es color morado oscuro.

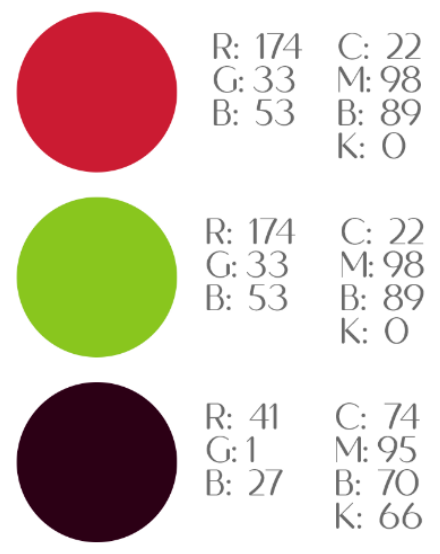

\section{d) Tipografía}

Se optó por la tipografía Quesha es una letra clásica y moderna a la vez (Ver cuadro 6). La forma de las letras está construida para que se distinga como orgánica y transmita una sensación de pureza. Es ideal para este producto pues va con todas sus características que busca transmitir. Además, esta tipografía es legible, elegante, amigable y se muestra como delicada y femenina, por lo que consideramos que al público objetivo le llamará la atención y la identificará rápidamente.

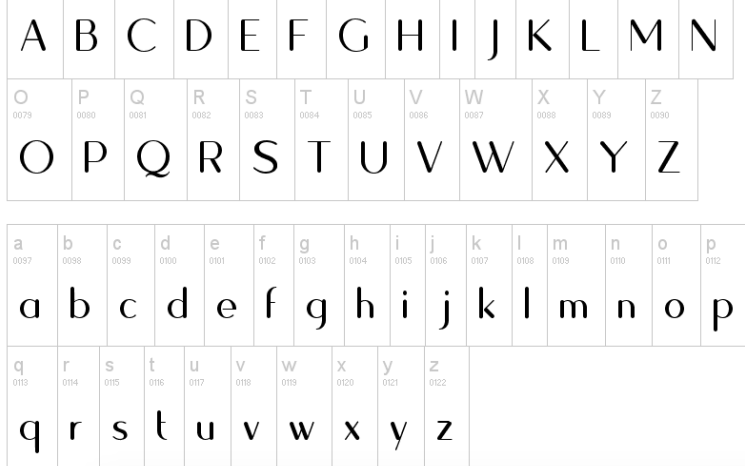

Tabla 6: Tipografía Quesha en minúsculas y mayúsculas

Fuente DaFont.com 


\section{e) Packaging}

Se elaboró una etiqueta que acompañe la botella de vidrio. En ella se incluyó al logotipo el texto: "Concentrado de chicha morada", el cual se encuentra dentro de una imagen que simboliza los granos del maíz con el fin de identificar fácilmente el producto. Además, se colocó en las esquinas de la etiqueta las características fundamentales de este concentrado que son: sin saborizante, sin preservante, sin azúcar añadida y sobretodo que es $100 \%$ natural. También se colocó para cuanto rinde $(2.5 \mathrm{lt})$ y de cuánto es la botella $(500 \mathrm{ml})$. En la parte posterior describe los ingredientes que posee y los beneficios que aporta a la alimentación y salud.

Todo lo mencionado irá sobre una etiqueta color blanco en la parte de arriba e irá cambiando a color morado oscuro en la parte de abajo. Además, este fondo morado tendrá un tramado simulando los granos del maíz. Todo ello para generar contraste entre logo y la etiqueta. Finalmente en la parte superior de la chapa de la botella tendrá como sello el logo de Quntu como tal.

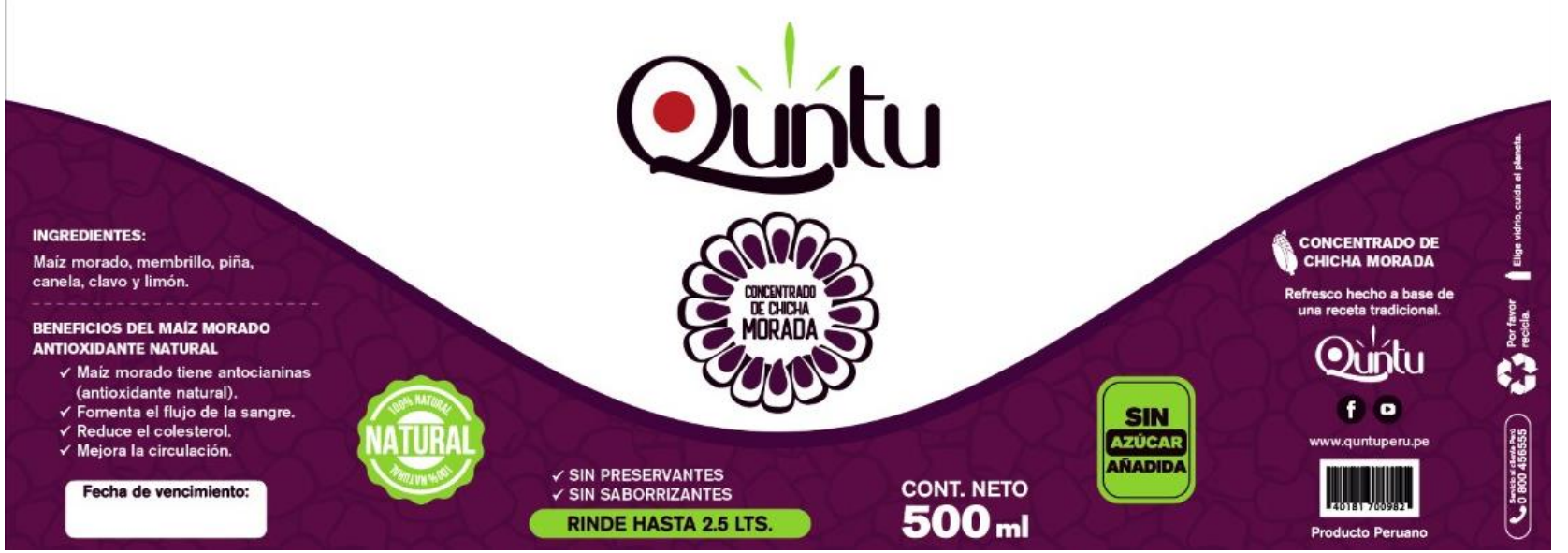




\section{d) Botella}

La botella escogida para el producto es de vidrio y de $500 \mathrm{ml}$. Es de este material pues se considera que conserva mejor el concentrado cuidando la calidad del producto. Además, el vidrio siempre otorga una sensación de elegancia, esta característica tiende a llamar mucho la atención y, finalmente, porque es eco-amigable y va con la tendencia por cuidar el medio ambiente.

El plus de esta botella es que puede ser reusable, complementando las de $3 \mathrm{R}$ de responsabilidad social (reciclable y reducible).

Con respecto a su forma, se trató que se parezca en lo mayor posible a un maíz morado y que dé esa sensación. Que no sea ni ancho ni delgado y que tanto la parte de arriba como la de abajo mantenga el grosor parecido.

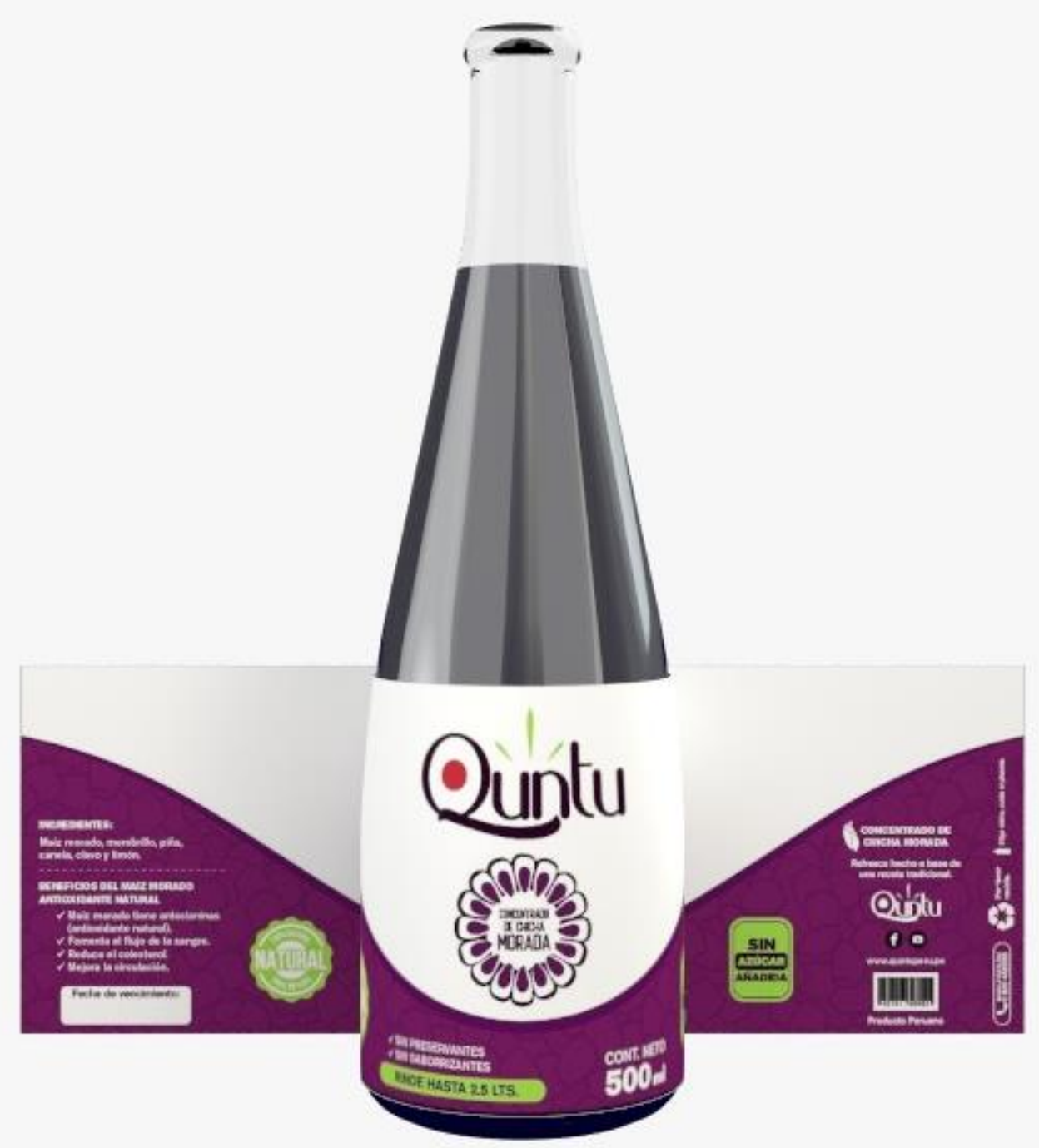




\subsection{Tono de comnicación}

a) Posicionamiento deseado

Quntu, el concentrado de chicha morada, elaborada con la receta tradicional casera. Es una bebida sana que no contiene saborizantes ni preservantes ni azúcar añadida.

\section{b) Promesa - Ventaja diferencial}

Quntu, concentrado de maíz morado combinado con frutas y especias que mantiene los valores nutricionales y beneficiosos para la salud del maíz morado: antioxidante natural.

\section{c) Razones para creer}

Este concentrado es $100 \%$ natural, no contiene preservantes, saborizantes, ni azúcar añadida. Además, en su composición no solo se hace presente el maíz morado, sino que está combinado con frutas y especias naturales. Por su parte, brinda grandes beneficios a la salud, pues "cada granito de esta mazorca es una bomba contra los radicales libres. Ayuda a prevenir todo tipo de trastornos y favorece la regeneración de los tejidos". (Cuerpo y mente, 2019)

d) Valores

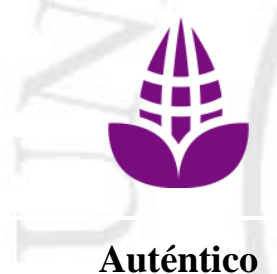

Auténtico

\section{Comprometido con la Salud}

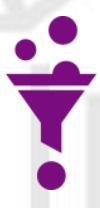

Práctico

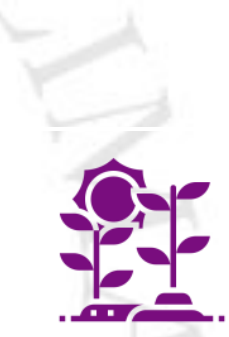

Transparente
Conservamos lo nuestro y lo mantenemos presente
Queremos que te mantengas lo más saludable posible

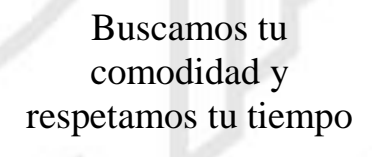

Brindamos un producto elaborado de la mejor cosecha de maíz y frutos

\section{e) Personalidad de la marca}

Es fresca, natural y elegante. Utiliza un lenguaje amigable y te llega a convencer de lo beneficiosa que es y del buen sabor que proporciona.

\section{f) Misión de marca}

Quntu, concentrado de chicha morada contribuye con la alimentación y la salud de las familias peruanas siendo un producto $100 \%$ natural que no contiene preservantes, ni saborizantes, ni azúcar añadida. 


\section{CAMPAÑA DE LANZAMIENTO}

La campaña de Quntu se centrará en el lanzamiento del producto al mercado. En este caso, la etapa principal del journey es el awareness y consideración, pues hay un público consciente de que el consumo de productos naturales es mejor y beneficioso e incluso saben que la chicha morada de por sí es saludable, pero no conocen cuáles son esos beneficios.

\section{Concepto de campaña}

"Quntu cuidamos la receta, cuidamos tu familia"

\section{Eslogan del producto}

"Quntu, auténtica receta tradicional"

El concepto creativo de la campaña de lanzamiento busca reflejar que Quntu es un concentrado $100 \%$ natural basada en la auténtica receta tradicional de chicha morada y que contiene grandes beneficios para la salud.

Se plasmará en medios como la mejor opción en concentrados de cereales, frutas y bebidas nutritivas, pues se rescatará los beneficios que tiene consumirla, además de hacer hincapié en que es un producto sin preservante, ni saborizantes, ni azúcar añadida.

\subsection{Objetivos de marketing}

- Lanzar una marca de concentrado de chicha morada y que consiga ser recordada por nuestro público objetivo.

- Lograr ser la favorita en relación a la competencia en un período de un año.

\subsection{Objetivos de comunicación}

- Dar a conocer Quntu, un nuevo concentrado de chicha morada 100\% natural.

- Destacar que Quntu contiene grandes beneficios para la salud.

- Generar conocimiento acerca de su sencilla forma de ser preparada.

- Informar sobre los puntos de venta.

\subsection{Sobre la campana}

- La campaña tendrá una duración de dos meses. Inicia en Junio y termina en Julio. El lanzamiento se realizará durante las dos primeras semanas de Junio y el resto de días será de mantenimiento.

- El presupuesto asignado es de $\$ 500,000$ y será usado en su totalidad por la importancia de generar impacto, visibilidad y conocimiento de la marca.

- Todos estos elementos serán visualizados en el capítulo 5. 


\subsection{Estrategia de medios}

Para lograr los objetivos, se realizó una estrategia de lanzamiento que implica utilizar los medios tradicionales y modernos en un $360^{\circ}$. Los principales objetivos y el journey del consumidor, permite centrar la campaña en dos factores esenciales: awareness y consideración.

Toda descripción de acciones específicas por medio y presupuesto distribuido se verá en el capítulo 5 del presente documento. Dicha información es sacada de América TV 2018, Latina 2016 y ATV 2016. En el caso de medios escritos MediaKit fue la referencia. Los costos de producción son cotizaciones realizadas a las agencias que en esta parte se menciona, por lo tanto es información de primera mano. Finalmente, los medios escogidos son fiel referencia a la investigación preliminar realizada del mercado y del público objetivo, y finalmente a APEIM.

En búsqueda de complementar los medios y trabajar en una primera etapa de iniciación, se considera oportuno llevar al consumidor por una ruta de concientización de la marca que implica tres grandes etapas a nivel masivo:

\section{a) Awareness: conocimiento del producto}

En esta etapa se realizarán acciones de conocimiento masivo - pero a la vez segmentado- del producto. Incluirán acciones con medios tradicionales como televisión, paneles y prensa; así como, una web informativa y Facebook como primera red social.

Es importante destacar los atributos que se busca reflejar de la marca, basándose en dos estrategias básicas de publicidad: emociones y racionalidad. De esta manera, en una segunda fase el producto podrá continuar hablando de lo tradicional y beneficioso que es este refresco. Es crucial conservar los valores, pues de aquí depende el posicionamiento del producto.

\section{b) Consideración: cómpralo, te conviene}

También basado en una estrategia básica de la publicidad, en esta etapa que complementa la anterior, se buscará hacer alusión a las experiencias no vividas o por vivir. Debido a que el producto no es listo para beber, se debe invitar al público a conocer cómo se prepara, su practicidad, su sabor, su rendimiento.

Acciones como BTL: ferias, activaciones y degustaciones, serán claves para que la experiencia del consumidor inicie antes de la compra y lo convenza de adquirir una y otra vez el refresco.

Adicionalmente, se requiere de pauta publicitaria en medios informativos como lo son los digitales. Es importante, pues el ama de casa no conoce el producto y va buscar de qué trata, no ha visto el spot publicitario y podrá verlo navegando en sus noticias de Facebook, o simplemente leerá lo que tanto le gusta con información de un producto natural como lo es Quntu. Se sigue buscando continuamente posicionarse en la mente del consumidor. 


\section{c) Nurturing: comprador informado}

Para continuar cumpliendo los objetivos y sin discriminar las etapas anteriores, más bien apoyándose, se realizarán acciones de nutrición de contenidos.

Basados en una estrategia de content marketing y apoyados de influencers y compradores habituales, los medios digitales principalmente estarán llenos de información que haga de las amas de casa compradoras informadas. No solamente se hablará de beneficios, también se destacarán experiencias que garanticen el sabor natural de chicha morada y qué tan fácil y sencillo puede ser su preparación.

Asociado a la etapa 1: cuando las amas de casa naveguen usando ciertas palabras claves como "natural", "nutrición”, "recetas", aparecerá información relacionada al contenido de valor.

Asociado a la etapa 2: siempre habrá un nutricionista informando los beneficios del producto final, incluyendo los beneficios de cada fruto que contiene.

\subsubsection{Mix de medios}

\subsubsection{Medios ATL}

\subsection{Televisión}

Se decidió por realizar publicidad principalmente para Televisión, ya que como se mencionó en descripción de público objetivo las amas de casa consumen más este medio y en diferentes horarios, pero sobretodo en las tardes y noches según Ipsos.

Los canales más vistos son América TV, Latina y ATV por los que son escogidos para invertir en la aparición del spot y en menciones dentro de diferentes programas.

Por otro lado, según Ipsos los programas que son los favoritos de las amas de casa son, en primer lugar, los noticieros seguido de telenovelas, las películas se llevan el tercer lugar y el cuarto programas de espectáculos. Tanto este factor y como el horario han sido determinantes para escoger los programas.

\section{a) Product placement}

Esta mención se realizará dos veces a la semana durante los dos meses de duración de la campaña. Luego se evaluará continuación y mejora.

\section{Latina "Mujeres al mando" (Ver tabla 7)}

En dicho programa la mención la deberán hacer Jazmín Pinedo y Karen Schwarz quienes simularán una conversación entre mamás. Ambas deberán leer el guión a través del teleprompter en donde resalten los beneficios de este nuevo producto y que lo recomienden porque ya lo probaron con su hijos. Esta mención tiene una duración de 30" 


\begin{tabular}{|c|c|c|}
\hline Programa & Guión & Acciones \\
\hline $\begin{array}{l}\text { Mujeres al } \\
\text { mando }\end{array}$ & $\begin{array}{l}\text { Jazmine: Karen no se que darle de beber a Khalessi no tengo } \\
\text { tiempo de prepararle bebidas naturales y a veces no me recibe } \\
\text { agua } \\
\text { Karen: pero, chinita, dale Quntu } \\
\text { Jazmine: ¿Quntu? } \\
\text { Karen: Es el nuevo concentrado de chicha morada } 100 \% \\
\text { natural sí } 100 \% \text { natural como preparado por ti. Lo mejor de } \\
\text { todo chinita es que es beneficioso para nuestras pequeñas. } \\
\text { Jazmine: ¡Wow! ¡No sabía eso! y no me digas que no tiene } \\
\text { saborizantes, ni preservantes, ni azúcar añadida } \\
\text { Karen:Así es y rinde hasta } 2.5 \text { litros de agua } \\
\text { Ambas: Quntu, auténtica receta tradicional. ¡Gracias Quntu! }\end{array}$ & $\begin{array}{l}\text { Jazmine } \\
\text { camina } \\
\text { conversando } \\
\text { con Karen y } \\
\text { llegan a la } \\
\text { mesa donde se } \\
\text { ven los } \\
\text { productos } \\
\text { Quntu y una } \\
\text { jarra ya lista } \\
\text { de la chicha } \\
\text { morada. } \\
\text { Jazmin coge el } \\
\text { producto, lo } \\
\text { mira y lo } \\
\text { muestra a la } \\
\text { cámara. }\end{array}$ \\
\hline
\end{tabular}

Tabla 7: Guión teleprompter 1.

\section{América TV "En boca de todos" (Ver tabla 8)}

En dicho programa la mención la deberá hacer Maju mantilla o Tula Rodriguez. Ellas deberán leer un guión a través del teleprompter en donde resalten los beneficios de este nuevo producto y que lo recomienden ya que ellas lo han probado junto a sus hijos. Esta mención tiene una duración de 30 ".

\begin{tabular}{|c|c|c|}
\hline Programa & Guión & Acciones \\
\hline $\begin{array}{l}\text { En boca de } \\
\text { todos }\end{array}$ & $\begin{array}{l}\text { Maju: ¡Mamitas! ¿Ya probaron Quntu? Es el nuevo concentrado } \\
\text { de chicha morada } 100 \% \text { natural, si } 100 \% \text { natural como } \\
\text { preparado por ti. No contiene saborizantes, ni preservantes, ni } \\
\text { azúcar añadida y está preparada en base a la receta tradicional } \\
\text { casera de chicha morada. Lo mejor de todo es que es } 100 \% \\
\text { beneficioso para tus hijos, se prepara rápidamente y rinde hasta } \\
\text { para } 2.5 \text { litro de agua. Yo ya lo preparo todas las mañanas para } \\
\text { la lonchera de mi hijo y ¿tu? } \\
\text { ¡YA LO SABEN, QUNTU AUTÉNTICA RECETA } \\
\text { TRADICIONAL! ¡GRACIAS QUNTU! }\end{array}$ & $\begin{array}{l}\text { Maju/Sheyla } \\
\text { camina hacia } \\
\text { la mesa donde } \\
\text { están los } \\
\text { productos } \\
\text { Quntu y los } \\
\text { insumos con } \\
\text { los que ha sido } \\
\text { preparado } \\
\text { como el maíz } \\
\text { morado, piña } \\
\text { cortada, } \\
\text { membrillo, } \\
\text { canela y clavo }\end{array}$ \\
\hline
\end{tabular}

Tabla 8: Guión teleprompter 2. 


\section{b) Spot publicitario}

De acuerdo a las preferencias encontradas, los horarios favoritos permite hacer selección de ciertos programas para la transmisión del spot publicitario durante la tanda comercial. Se distribuyó la pauta por semana entre los siguientes programas:

\section{- Latina}

- Válgame Dios con Rodrigo y Gigi - 1pm

- Tengo algo que decirte con Lady Guillén - 4 pm

- Reporte Semanal - Sábado - 8:30 am

\section{- América TV:}

- En boca de todos con Maju Mantilla y Tula Rodriguez - 1 pm

- Novela de estación: De vuelta al barrio - 8:30 pm

Estas en todas - 9:00 am

El artista del año con Gisela Valcárcel - Sábados - 9 pm

Cuarto Poder - Domingo - 8 pm

- ATV

- La Firme con Magaly Medina - 9:15 pm

\section{Concepto del spot publicitario $\underline{\text { (Anexo } 3 \text { y } 4)}$}

Se grabará un spot publicitario de 43 segundos transmitido durante los dos meses de campaña y será emitido durante la tanda comercial de los programas descritos más arriba.

El comercial, al igual que toda la campaña, se centra en que Quntu cuida la receta tradicional, cuida a tu familia. Es por ello que, como producto beneficioso para la salud y dirigido a las amas de casa modernas, utilizaremos como imagen del spot a Maria Pia Copello, un gran referente para el target. Ella contará junto a su pequeña hija Catalina los beneficios que trae consumir productos naturales y la preocupación por todas las madres de que sus hijos crezcan sanos demostrando que Quntu es el concentrado que cuida la receta tradicional casera de chicha morada y que a la vez cuida a tu familia.

\subsection{Radio}

Como se mencionó anteriormente la radio está posicionado en el tercer lugar como medio de entretenimiento de las amas de casa. Por ello, se optó por realizar un comercial que será emitido durante las mañanas, ya que, según Ipsos, este horario es el preferido para ellas y en dos radios locales. 
Según el CPI (Compañía Peruana de Estudios de Mercado), RPP es el favorito por el nivel socioeconómico A y B y Karibeña por los del C. El spot tendrá una duración de 30" por ser un producto nuevo que se está lanzando al mercado. Por último, se contratará a María Pía Copello para que sea protagonista del spot al igual que en televisión (Ver Anexo 5).

Este comercial será emitido durante los siguientes programas

RPP

- La rotativa del Aire -5 am - 8 am

- Ampliación de Noticias - 8 am - 10 am

- Encendidos - $10 \mathrm{am}-12 \mathrm{pm}$

\section{La Karibeña}

- Mañanas en el Karibe - 8 am - 9 am

- La ruleta Karibeña - 9 am - 10 am

- Los Karibepedidos - 10 am - 11 am

\subsection{Prensa}

a) Publi-reportaje

Según APEIM, el segmento A (97\%), B (88\%) y C (73\%) son los que más leen. Dentro de sus favoritos se encuentra: El Comercio, Correo, La República; mientras que Caretas, Somos y Gente lidera en revistas. (APEIM, 2005)

\section{Presentes en "Reporte semanal"}

Toda la campaña de lanzamiento irá acompañada por una nutricionista. Entonces, iniciará hablando de la importancia de los alimentos y bebidas en la salud de grandes y chicos, la mejorada ley de alimentación, la tendencia del valor nutricional, entre otros factores. Además, explicará los beneficios de Quntu para ciertas personas, lo saludable y aportante a la alimentación de los niños, la prevención en muchas enfermedades gracias al maíz morado. Finalizará con el aporte de este nuevo producto al mercado, especialmente a las amas de casa que tienen un estilo de vida agitado. Se considera la participación de un vocero de la empresa que lanzará al mercado este producto, puede ser el director de marketing o comercial.

\section{Presentes en "Somos"}

Para el publireportaje en Somos, se trabajará con la vocería del representante de marketing de la empresa que lanzará este producto. Esto debido a que el consumo de bebidas naturales y los hábitos de compra de un ama de casa son más tendencias que alguien de esa profesión puede explicar. 
Con la misma narrativa del reportaje en televisión, debe iniciarse por las tendencias actuales de consumo, las preferencias de las amas de casa y el cuidado de los niños y de la familia en general. El aporte a la sociedad de un producto como este y el valor ancestral que tiene la chicha morada. Acompañado irá una infografía sobre los beneficios del maíz (Anexo 6). Esta información será apoyada por un nutricionista.

\section{b) Rueda de prensa}

Quntu será lanzado por importante empresa nacional y para ello, el equipo de marketing realizará acciones de relacionamiento público. Se redactará una nota de prensa con la información.

El contenido se basa principalmente en la apuesta por las bebidas naturales y ancestrales, además que hoy existe una necesidad por encontrar productos listos para preparar. La empresa también apostará por los beneficios que este tipo de bebidas trae a la salud, especialmente se explicará el valor de un cereal considerado Super Food, ya que el maíz morado contiene antocianina y muchos no lo sabían. Finalizará con el resultado de una investigación y el por qué las amas de casa lo preferirán.

Para ello, se busca en profundidad contactos de distintos medios de interés como El Comercio, Ojo, Trome, Gestión, Publimetro, Mercado Negro, entre otros; esperando que hagan pública esta nota y dejando carta libre la invitación a una entrevista, que seguramente será solicitada al tratarse de una empresa nacional en crecimiento.

Para complementar, se trabajará directamente con los medios en una rueda de prensa. El evento será dirigido por los principales representantes de la empresa y también el área de marketing hará degustar el sabor en el catering que acompaña el evento, de forma que experimenten y hablen de su propia experiencia en la nota.

\subsubsection{Acciones BTL}

Debido a que Quntu es un producto para preparar, pero instantáneo, se debe llegar al consumidor adelantando su experiencia final. Es decir, generar contacto con el producto final a través de activaciones y convenciendo al consumidor que es la auténtica receta casera.

\subsection{Experiencias con el producto}

\section{a) Degustaciones en supermercados}

Vivanda, Wong, Plaza Vea y Metro serán los principales supermercados donde se dispondrá de degustadoras el primer mes de campaña durante tres días de cada semana. 


\section{La dinámica de degustaciones es la siguiente:}

Las degustadoras tendrán un módulo atractivo y con los colores y formas representativos de la marca. Deberá vestir una blusa blanca y pullover morado con un atado de cabello sencillo. Deberán invitar a degustar del sabor a las personas que transiten por la zona de refrigerados, especialmente. Les invitará a acercarse al módulo y conocer de la preparación, para lo cual mostrarán que una botella pudo rendir para la cantidad del jarrón con caño que estará en el módulo. Además, deberá mencionar los beneficios del maíz morado. Ella invitará a comprar el producto ahí mismo con un número de ticket a cancelar en caja o lo hará pasar a la sección donde podrá encontrarlo.

\section{b) Activaciones en centros comerciales}

Las activaciones serán en los principales centros comerciales en donde reside el público objetivo de Quntu La quincena de Junio se realizará el evento en el Jockey Plaza y en Real Plaza Salaverry, a fines de Junio será en La Rambla San Borja y en Plaza San Miguel. Hacia Julio se realizará en Real Plaza Centro Cívico y Real Plaza Primavera.

\section{La dinámica de activaciones es la siguiente:}

La activación tendrá una estrategia de gamificación, donde se invitará a las personas que transiten - especialmente a mujeres que estén con niños- a degustar de tres chichas servidas al instante. Se preguntará cuál considera es la auténtica receta tradicional y si contesta acertadamente, se revelará si es Quntu o es una marca alternativa (la cual puede ser concentrado o lista para beber).

Al ganador se obsequiara un bucket de Quntu que incluye bebidas y merchandising.

Estas activaciones se realizarán durante 3 horas del día y cada quincena de mes en cada establecimiento mencionado. Tendrá la participación de un animador, un vendedor y dos anfitrionas que apoyen con el servido y entrega de premios.

\section{c) Participación en ferias gastronómicas}

Las ferias se han convertido en un espacio festivo, una ocasión para vivir experiencias y compartir en familia. Hoy en día, existen en Lima diversas ferias por artículos, rubros y hasta estilos de vida, donde lo orgánico se ha vuelto algo novedoso y a donde todas quieren ir. Expresando una tendencia, lo convierte en un espacio ideal tanto para expositores, quienes pueden transmitir la vivencia de su marca con mayor calidez y cercanía, como para los visitantes, quienes pueden probar, mirar, tocar de primera mano.

De acuerdo a la necesidad y origen del producto, el target, y la disposición misma de las ferias actuales, se decidió la participación en el siguiente espacio: 
- EcoJockey: el año anterior se realizó esta feria desde el 1ero de Julio, donde promueven el consumo de alimentos y bebidas naturales en $650 \mathrm{mts} 2$ de espacio todos los domingos durante 3 fechas. Para Quntu, este centro comercial es un espacio donde suele transitar público del segmento A y B, amas de casas y familias en general, por lo que participar será imprescindible siempre para el 2019. (Publímetro, 2018)

\section{d) Merchandising}

Para el apoyo visual, se deberá considerar módulo, banner, merchandising (tote bag, tomatodo, llaveros), bucket, vestimenta de anfitrionas, globos, manajes reciclables. (Anexo 7 y 8).

\subsection{Publicidad fuera de casa}

\section{e) Vallas}

Se decidió por colocar vallas de proximidad a supermercados, pues según estudios de Ipsos, las amas de casa de nivel socioeconómico A y B suelen ir a estas grandes tiendas una vez a la semana y los de nivel socioeconómico $\mathrm{C}$ un par de veces al mes. Se consideró que por su continua presencia, era importante la realización de este tipo de publicidad en vía pública. Según un estudio realizado por Apeim (Asociación Peruana de Empresas de Investigación de Mercado) las personas del nivel socioeconómico A viven en zonas como Surco, Miraflores, La Molina, San Isidro y San Borja. Por otro, lado el nivel socioeconómico B reside mayormente en San Miguel, Pueblo Libre, Magdalena, Jesús María y Lince. Finalmente el nivel socioeconómico C vivie en Ate, Barranco, Chorrillos y Surquillo.

Debido a ello los lugares estratégicos escogidos han sido las avenidas grandes de mayor tránsito que estén cerca a supermercados o centros comerciales y se encuentren en los distritos mencionados. Se optó por escoger seis vallas en total durante los dos meses que durará la campaña. El primer mes tres de ellas estarán posicionados en tres distritos diferentes y el segundo mes de igual manera.

Se podrá visualizar el acabado final de la valla en el Anexo 9:

\begin{tabular}{|l|l|l|l|}
\hline ELEMENTO & DISTRITO & DIRECCIÓN & MES \\
\hline VALLAS & SAN BORJA & $\begin{array}{l}\text { Calle Morelli 101 con Javier Prado 2100 } \\
\text { (Cerca a Wong) }\end{array}$ & JUNIO \\
\hline VALLAS & MIRAFLORES & $\begin{array}{l}\text { Av Benavides con Av República de } \\
\text { Panamá (Cerca al SuperMercado Wong) }\end{array}$ & JUNIO \\
\hline VALLAS & JESÚS MARÍA & $\begin{array}{l}\text { Av Salaverry 1810 con Av San Felipe } \\
\text { (Cerca al centro comercial Salaverry) }\end{array}$ & JUNIO \\
\hline VALLAS & SURCO & $\begin{array}{l}\text { Av Javier Prado 4200 (Cerca al Jockey } \\
\text { Plaza) }\end{array}$ & JUNIO \\
\hline
\end{tabular}




\begin{tabular}{|l|l|l|l|}
\hline VALLAS & SAN MIGUEL & Av La Marina 2500 (Cerca al Metro) & JULIO \\
\hline VALLAS & SURQUILLO & $\begin{array}{l}\text { Av Andrés Aramburú 720 (Cerca al } \\
\text { Metro) }\end{array}$ & JULIO \\
\hline VALLAS & SURCO & Av. La Encalada cuadra 5 (Vivanda) & JULIO \\
\hline VALLAS & SAN ISIDRO & Av. 2 de mayo cuadra 5 (Vivanda) & JULIO \\
\hline VALLAS & SAN ISIDRO & $\begin{array}{l}\text { Av. Camino Real cuadra 8 (CC Camino } \\
\text { Real) }\end{array}$ & JUNIO \\
\hline
\end{tabular}

Tabla 9: Ubicación de vallas publicitarias en Lima Moderna.

Fuente: APEIM 2005.

\section{f) Bodegas: visicooler y jalavistas}

De acuerdo al a información anterior, se ofrecerá al por mayor este producto en las principales bodegas de Lima, esta vez considerando el $90 \%$ de los distrito donde reside el segmento A, B y C según APEIM.

Es entonces que se podrá encontrar Quntu en:

1. Lince

2. Surquillo

3. Barranco

4. Chorrillos

5. San Miguel

6. Pueblo Libre

7. Jesús María
8. Magdalena

9. Santiago de Surco

10. San Borja

11. La Molina

12. Miraflores

13. San Isidro

14. Los Olivos

De acuerdo al espacio de la bodega, se ofrecerá como valor adicional un visicooler y también jalavistas para informar sobre el nuevo producto (Anexo 10).

\subsubsection{Comunicación digital}

Según las preferencias de consumo del público objetivo, un segundo puesto ocupa "internet" como medio de entretenimiento e información. Es por ello que se van a desarrollar tres estrategias digitales básicas para la presencia de Quntu en el mundo online.

\section{a) Influencer: Mamás blogueras}

Gracias a un breve estudio realizado por Métrica (Métrica, 2018), consultora de marketing, se puede conocer el boom de los bloggers y el eco-content viral que generar gracias a su masivo público seguidor. Una comunidad emergente en nuestro país son las mamás blogueras, mommy bloggers o mommy influencer, como ellos mismos las denominan.

Dice este blog que la idea nació en el 2011 y el boom fue hacia el 2016 y 2017 por una sensación de querer ayudar a otras madres primerizas e intercambiar experiencias. El $80 \%$ de ellas no 
solamente cumple un rol de ama de casa, mamá, sino que también trabaja y estas son justamente las características que tiene nuestro público objetivo actual.

El diario Publimetro publicó hacia el 2018 que existen más de 186 blogs dirigidos por mamás peruanas. Incluso una comunidad oficial y única en su año que es "Mamás blogueras peruanas" formado por 30 editores que redactan de temas relacionados. (Publímetro, 2018)

Es así que para el lanzamiento se tendrá un grupo pequeño de mommy bloggers. Este equipo de streaming será denominado \#AuténticasMamasQ y será encabezado por las blogueras más rankeadas (Anexo 10):

Mami-s-cool: es un diario de Kristin Morris de 32 años de edad, mamá de dos niños. A la fecha, tiene 105.903 seguidores en Facebook, 19.3k en Instagram y 1.8M en YouTube. La pueden encontrar como@mamiscool en redes sociales.

Ella será la principal imagen de Quntu en redes sociales, por tanto se solicitarán las siguientes acciones durante los meses de campaña.

- Vlog en YouTube sobre los beneficios del maíz morado, ingrediente principal de Quntu.

- Replica de video YouTube en Facebook.

- Post pagado en Facebook sobre el nuevo producto que ella recomienda por sus beneficios, sabor y rápida preparación.

- Posts orgánicos sobre alimentación donde acompañen la comida con Quntu, una auténtica receta tradicional de chicha morada. Se podrá ver en la programación de publicaciones.

- Una publicación especial sobre los beneficios del maíz morado que conserva Quntu.

- Tips en su blog sobre el acompañamiento de comidas con bebidas beneficiosas y naturales como lo es Quntu.

Como apoyo, se solicitará a las siguientes bloggers pertenezcan al team. Solo se dará un obsequio de bienvenida que deberá ser posteado en Facebook y compartan el Fanpage con un video del producto.

Soy mamá y no me compadezcas: un blog personal de Nathalie Otarola de 31 años, mamá de dos niños. A la fecha tiene 104.707 seguidores en Facebook, 8M en Instagram. Se encuentra en redes como @soymamaynomecompadezcas en redes sociales.

Mamá ¿yo?: también cuenta el día a día de Melina Félix de 31 años y es mamá de una niña. A la fecha tiene 90,906 seguidores en Facebook y 3M en Instagram. Se encuentra en todas las redes como@mamayoelblog o solo@mamayo,dependiendo de la plataforma. 


\section{b) Facebook: Quntu Perú Oficial}

El estudio de amas de casa de Ipsos revela que ahora el 57\% son mujeres internautas (IPSOS, 2018), pero siguen siendo novatas en el aprovechamiento de las TIC. En su mayoría son del NSE A, B y C y tienen un trabajo fijo o independiente. "La gran mayoría se entera de las ofertas por televisión y radio, aunque la publicidad por este último medio de comunicación parece influir más en su decisión de adquirir algo", explicó Javier Álvarez, gerente de Cuentas y Estudios Multiclientes de Ipsos Perú para diario Andina. (Álvarez, 2018)

Por lo tanto, se ha decidido consolidar el mayor esfuerzo en esta red social evaluando en una segunda etapa Instagram.

La personalidad de Quntu será la misma en todas sus comunicaciones, pero en este espacio tendrá la posibilidad de hablar directamente a las mujeres, mamás y amas de casa que les toca ser prácticas sin olvidar que tienen a cargo la salud y alimentación de sus hijos. La naturalidad de Quntu le permite tener una imagen fresca, pero con carácter, que tiene experiencia y sabe de qué está hablando. Especialmente, te aconseja sobre lo que no sabías acerca de sus ingredientes naturales. Se preocupa por la tradicional receta, pero habla como una mamá moderna.

Según los insights obtenidos en el journey del consumidor y de acuerdo a los valores establecidos por Quntu, las publicaciones tendrán las siguientes características - se podrá revisar la sugerencia de publicaciones en Anexo 11:

\begin{tabular}{|l|l|l|l|}
\hline Tema & Objetivo & Descripción & Reason why \\
\hline Innovación & $\begin{array}{l}\text { Awareness } \\
\text { Conocimiento }\end{array}$ & $\begin{array}{l}\text { Descripción del producto, } \\
\text { marca, insumos, preparación, } \\
\text { origen. }\end{array}$ & $\begin{array}{l}\text { Valor auténtico } \\
\text { \#QuntuEsAuténtico }\end{array}$ \\
\hline Pragmatismo & $\begin{array}{l}\text { Branding } \\
\text { Consideración }\end{array}$ & $\begin{array}{l}\text { Beneficios para la para la salud, } \\
\text { alimentación, para } \\
\text { preparación rápida y } \\
\text { rendimiento familiar. }\end{array}$ & $\begin{array}{l}\text { Valor Práctico } \\
\text { \#RecentasQSaludables }\end{array}$ \\
\hline Poder & $\begin{array}{l}\text { Loyalty } \\
\text { Experiencia }\end{array}$ & $\begin{array}{l}\text { Recomendación team de } \\
\text { mamás, presentes en espacios } \\
\text { relacionados a lo natural. }\end{array}$ & $\begin{array}{l}\text { Valor trasparente } \\
\text { \#MamásAuténticasQ }\end{array}$ \\
\hline Protección & $\begin{array}{l}\text { Loyalty } \\
\text { Lealtad }\end{array}$ & $\begin{array}{l}\text { Recomendaciones de recetas, } \\
\text { tips, cuidado familiar. }\end{array}$ & $\begin{array}{l}\text { Valor salud } \\
\text { \#RecentasQSaludables }\end{array}$ \\
\hline
\end{tabular}

Tabla 10: Matriz de publicaciones por objetivo con descripción. 
Pauta en Facebook: debido a que necesitará de visibilidad, para luego posicionarse, se realizará pauta por los dos meses de campaña. La segmentación está dirigida a mujeres de 28 a 45 años de edad. Para esta acción se ha considerado la siguiente segmentación en Facebook con el fin de que le den like a la página:

- Ubicación: Lima - Perú

- Sexo: Femenino

- Edad: 28 a 45 años

- Intereses: comida, pastelería, recetas, compras, familia, amistad, maternidad, paternidad, arte culinario, comer, cocina, food, gastronomía, gourmet, pasatiempo, moda

- Datos demográficos: Padres con hijos de 3 a 18 años.

Para el primer mes de pauta, se colocará el spot publicitario (Ver anexo x) realizado para televisión. Para el segundo mes, se tendrá el apoyo de Mami-s-cool con su primer Vlog sobre los beneficios de Quntu. Se espera tener un promedio de 40k en dos meses.

\section{c) Website: Quntuperu.pe}

Toda marca necesita una carta de presentación, donde pueda archivar todo el contenido que no puede decir a través de los grandes medios o sirva de apoyo para las redes sociales. Por eso, se consideró imprescindible la creación de una página web.

De carácter meramente informativo, la web tendrá los tres aspectos básicos del posicionamiento: beneficiosa a la salud, receta y sabor tradicional, práctica de preparar. Además, habrán tres categorías de blog, pues se ha considerado necesario incorporar un espacio de conocimiento (ligado a la tercera estrategia de lanzamiento "nurturing"). Estas categorías son: Salud, Familia, Recetas. Todas en base a la comida y acompañado siempre de Quntu. Para poder visualizar un modelo, puede ingresar a www.quntuperu.pe.

\section{SEM:}

- Adicionalmente, se gestionará el pago de pauta en Google Search con palabras recomendadas como lo son "recursos naturales", "salud", "dieta", "tratamientos", "remedios", "bebidas energéticas", "belleza", "cuidado personal", "dieta saludable", "nature", "cocina", "recentas", entre otroas, para tener mayor visibilidad en buscadores. Permitirá que la marca tenga mayor alcance y visibilidad.

- De acuerdo a las provisiones de Google, se registraron en total 50 palabras claves asociadas para que aparezcan durante el mes de Junio y Julio en Google y los socios de búsqueda. Se espera obtener $6.8 \mathrm{k}$ en clic, $790 \mathrm{k}$ impresiones. El objetivo es netamente posicionamiento y conocimiento de la marca. 


\section{DISTRIBUCIÓN DE RECURSOS}

5.1. Presupuesto

\begin{tabular}{|c|c|c|c|c|c|c|c|}
\hline \multicolumn{8}{|c|}{ LANZAMIENTO QUNTU } \\
\hline ACCION & CANAL & DETALLE & VECES & FORMATO & PRECIO UNI \$ & TOTAL \$ & $\begin{array}{l}\text { TOTAL POR } \\
\text { CANAL }\end{array}$ \\
\hline \multirow{9}{*}{$\begin{array}{c}\text { ATL - } \\
\text { PRODUCCIÓN } \\
\text { DE SPOT } \\
\text { PUBLICITARIO } \\
(1)\end{array}$} & Concepto creativo & Agencia & 1 & Vez & $\$ 1,500.00$ & $\$ 1,500.00$ & \multirow{9}{*}{$\$ 51,200.00$} \\
\hline & Producción general & Agencia Pre y post producción & 1 & Vez & $\$ 35,000.00$ & $\$ 35,000.00$ & \\
\hline & Equipamiento & Agencia alquiler equipamiento & 1 & Vez & $\$ 3,500.00$ & $\$ 3,500.00$ & \\
\hline & Locación & Cocina vanguardista & 1 & Vez & $\$ 500.00$ & $\$ 500.00$ & \\
\hline & Catering & Para producción y actores & 1 & Horas & $\$ 200.00$ & $\$ 200.00$ & \\
\hline & Transporte & Alquiler de vehículo & 4 & Horas & $\$ 100.00$ & $\$ 400.00$ & \\
\hline & Adaptación de video & Para versión digital & 1 & Vez & $\$ 600.00$ & $\$ 600.00$ & \\
\hline & Personaje principal & Maria Pia Copello - imagen & 1 & Vez & $\$ 6,000.00$ & $\$ 6,000.00$ & \\
\hline & Personaje secundario & Catalina Copello & 1 & Vez & $\$ 3,500.00$ & $\$ 3,500.00$ & \\
\hline \multirow{10}{*}{$\begin{array}{c}\text { ATL - COSTO } \\
\text { DE } \\
\text { PARTICIPACIÓN } \\
\text { EN } \\
\text { PRINCIPALES } \\
\text { CANALES } \\
\text { NACIONALES } \\
(2)\end{array}$} & América TV - 2018 & Auspicio Jun-Jul "En boca de todos" & 2 & Meses & $\$ 4,182.00$ & $\$ 8,364.00$ & \multirow{10}{*}{$\$ 266,225.00$} \\
\hline & América TV - 2018 & Spot Jun-Jul "De vuelta al barrio" & 2 & Meses & $\$ 7,676.00$ & $\$ 15,352.00$ & \\
\hline & América TV - 2018 & Spot Junio "Estas en todas" & 4 & Veces $\mathrm{x}$ mes & $\$ 2,323.00$ & $\$ 9,292.00$ & \\
\hline & América TV - 2018 & Spot Junio "El Artista del Año" & 4 & Veces $\mathrm{x}$ mes & $\$ 7,070.00$ & $\$ 28,280.00$ & \\
\hline & América TV - 2018 & Spot Julio "Cuarto poder" & 4 & Veces $\mathrm{x}$ mes & $\$ 5,252.00$ & $\$ 21,008.00$ & \\
\hline & Latina - 2016 & Mención Jun-Jul "Mujeres al mando" & 16 & Veces $\mathrm{x}$ mes & $\$ 1,162.12$ & $\$ 18,594.00$ & \\
\hline & Latina - 2016 & Spot Jun-Jul "Válgame Dios" & 16 & Veces $\mathrm{x}$ mes & $\$ 3,181.82$ & $\$ 50,910.00$ & \\
\hline & Latina - 2016 & Spot Jun-Jul "Tengo algo que decirte" & 16 & Veces $\mathrm{x}$ mes & $\$ 4,000.00$ & $\$ 64,000.00$ & \\
\hline & Latina - 2016 & Spot Jul "Reporte Semanal" & 4 & Veces $\mathrm{x}$ mes & $\$ 4,000.00$ & $\$ 16,000.00$ & \\
\hline & ATV - 2016 & Spot Jun "Magaly TV La Firme" & 8 & Veces $x$ mes & $\$ 4,303.03$ & $\$ 34,425.00$ & \\
\hline
\end{tabular}




\begin{tabular}{|c|c|c|c|c|c|c|c|}
\hline \multirow{4}{*}{$\begin{array}{c}\text { ATL - } \\
\text { PRODUCCIÓN }\end{array}$} & Producción & Costo de grabación & 1 & Vez & $\$ 70.00$ & $\$ 70.00$ & \multirow{6}{*}{$\$ 24,925.00$} \\
\hline & Locutor & Maria Pia Copello & 1 & Vez & $\$ 1,000.00$ & $\$ 1,000.00$ & \\
\hline & Estudio & Alquiler de estudio & 3 & Vez & $\$ 50.00$ & $\$ 150.00$ & \\
\hline & Jingle & Preparación jingle 30" & 1 & Vez & $\$ 795.00$ & $\$ 795.00$ & \\
\hline \multirow{2}{*}{$\begin{array}{c}\text { ATL - } \\
\text { APARICIÓN EN } \\
\text { RADIOS }\end{array}$} & RPP & Spot $30 "$ en RPP & 36 & Apariciones & $\$ 363.64$ & $\$ 13,091.00$ & \\
\hline & La Karibeña & Spot $20 "$ en La Karibeña & 36 & Apariciones & $\$ 272.73$ & $\$ 9,819.00$ & \\
\hline \multirow{4}{*}{$\begin{array}{c}\text { ALT - } \\
\text { RELACIONES } \\
\text { PÚBLICAS (3) }\end{array}$} & Latina - 2016 & Publireportaje "Reporte semanal" & 1 & Vez & $\$ 6,060.61$ & $\$ 6,061.00$ & \multirow{4}{*}{$\$ 17,820.00$} \\
\hline & Revistas & Publireportaje en "Somos" & 1 & Vez & $\$ 9,939.39$ & $\$ 9,940.00$ & \\
\hline & Evento prensa & Alquiler de local - Club Empresarial & 1 & Vez & $\$ 1,060.61$ & $\$ 1,061.00$ & \\
\hline & Relaciones públicas & Agencia PR por lanzamiento & 1 & Vez & $\$ 757.58$ & $\$ 758.00$ & \\
\hline \multirow{15}{*}{$\begin{array}{c}\text { BTL - } \\
\text { EXPERIENCIAS } \\
(4)\end{array}$} & Presentación & Modulo personal & 6 & Unidades & $\$ 75.76$ & $\$ 455.00$ & \multirow{15}{*}{$\$ 32,154.00$} \\
\hline & Presentación & Banner roll & 4 & Unidades & $\$ 36.36$ & $\$ 146.00$ & \\
\hline & Degustaciones & Degustadoras por fecha & 4 & Degustadoras & $\$ 969.70$ & $\$ 3,879.00$ & \\
\hline & Degustaciones & Menaje - valor en millar & 5 & Millares & $\$ 151.52$ & $\$ 758.00$ & \\
\hline & Degustaciones & Licencia de degustación Wong & 4 & Locales & $\$ 350.00$ & $\$ 1,400.00$ & \\
\hline & Degustaciones & Licencia de degustación Vivanda & 4 & Locales & $\$ 300.00$ & $\$ 1,200.00$ & \\
\hline & Degustaciones & Licencia de degustación Metro & 4 & Locales & $\$ 250.00$ & $\$ 1,000.00$ & \\
\hline & Degustaciones & Licencia de degustación Plaza Vea & 4 & Locales & $\$ 300.00$ & $\$ 1,200.00$ & \\
\hline & Activaciones & Licencia de activación CC 1 & 1 & Locales & $\$ 450.00$ & $\$ 450.00$ & \\
\hline & Activaciones & Licencia de activación CC 2 & 1 & Locales & $\$ 450.00$ & $\$ 450.00$ & \\
\hline & Activaciones & Licencia de activación CC 3 & 1 & Locales & $\$ 450.00$ & $\$ 450.00$ & \\
\hline & Activaciones & Licencia de activación CC 4 & 1 & Locales & $\$ 450.00$ & $\$ 450.00$ & \\
\hline & Activaciones & Licencia de activación CC 5 & 1 & Locales & $\$ 450.00$ & $\$ 450.00$ & \\
\hline & Activaciones & Licencia de activación CC 6 & 1 & Locales & $\$ 450.00$ & $\$ 450.00$ & \\
\hline & Activaciones & Animador por lugar y fecha & 6 & Día laboral & $\$ 300.00$ & $\$ 1,800.00$ & \\
\hline
\end{tabular}




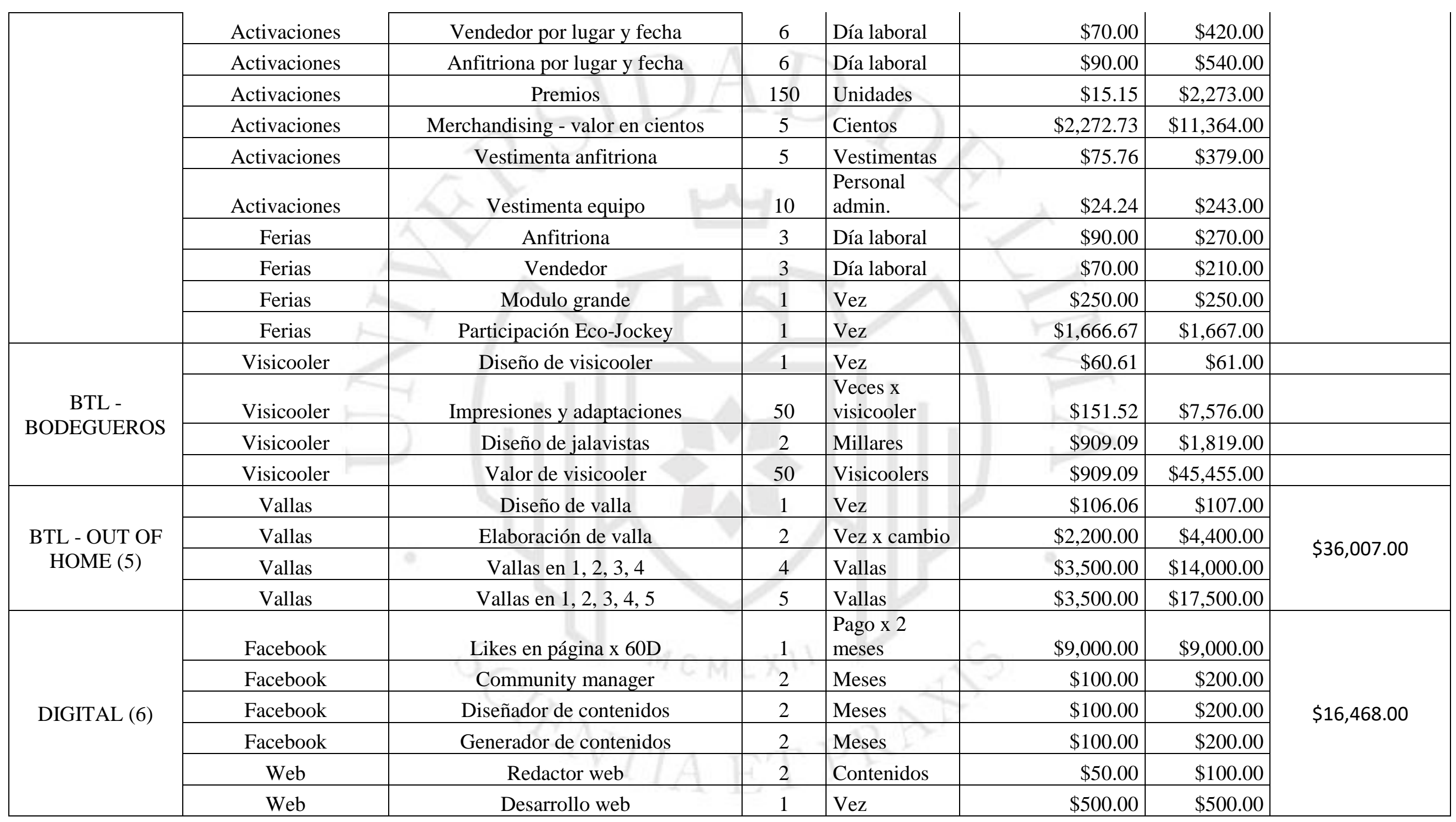




\begin{tabular}{|c|c|c|l|r|r|}
\cline { 2 - 6 } Web & \multicolumn{1}{|c|}{ Dominio } & 1 & Vez & $\$ 25.00$ & $\$ 25.00$ \\
\hline Google & Keywords en Google y socios & 2 & Meses & $\$ 1,121.21$ & $\$ 2,243.00$ \\
\hline Influencer (7) & Mami-s-cool - imagen & 2 & Meses & $\$ 1,000.00$ & $\$ 2,000.00$ \\
\hline Influencer & Mami iyo? - obsequio & 2 & Meses & $\$ 500.00$ & $\$ 1,000.00$ \\
\hline Influencer & Soy mamá y... - obsequio & 2 & Meses & $\$ 500.00$ & $\$ 1,000.00$ \\
\hline
\end{tabular}

TOTAL

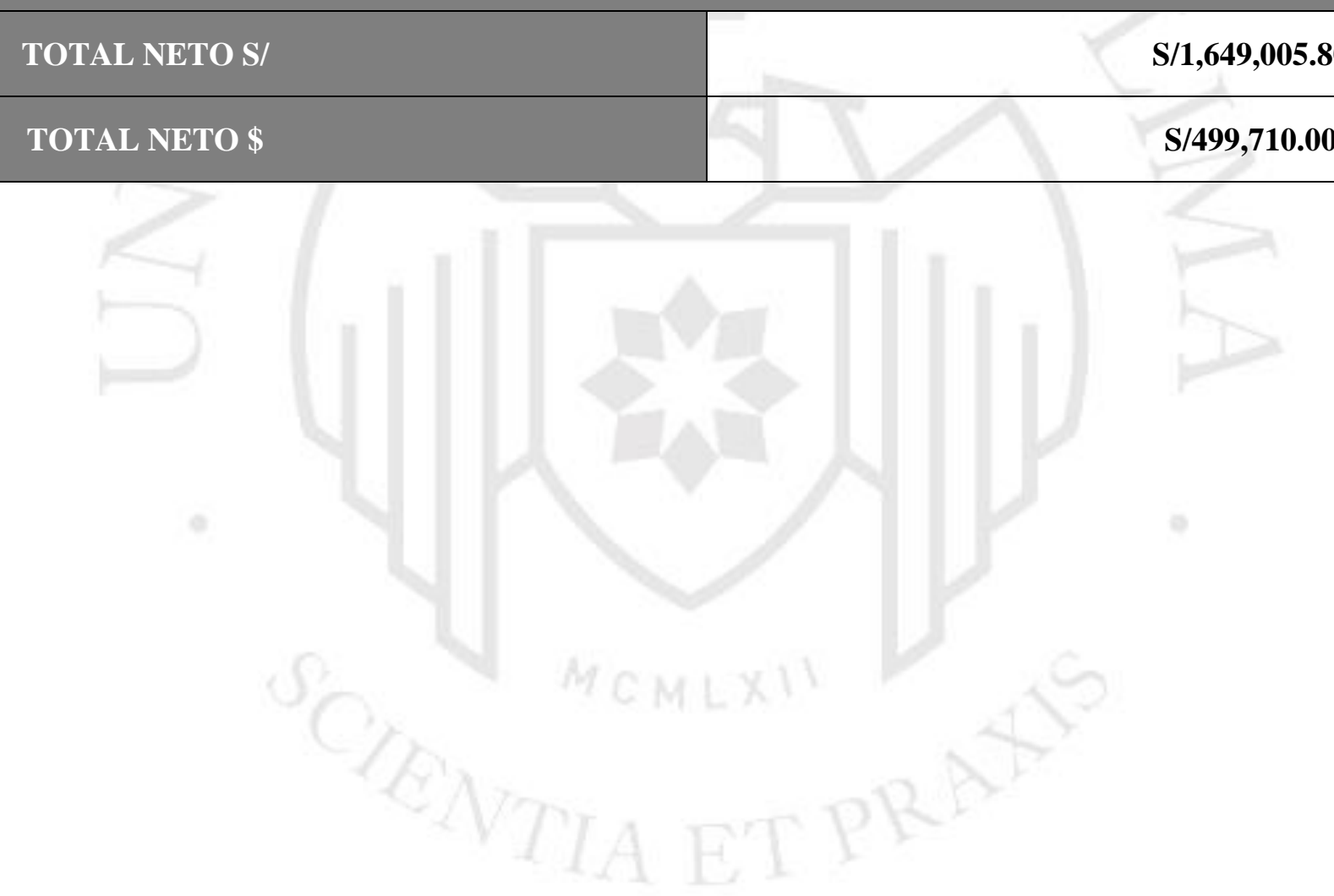




\subsection{Gantt de actividades}

\section{JUNIO}

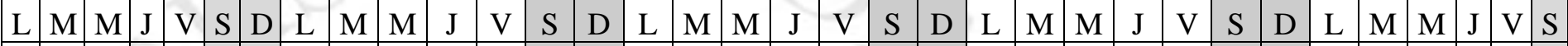

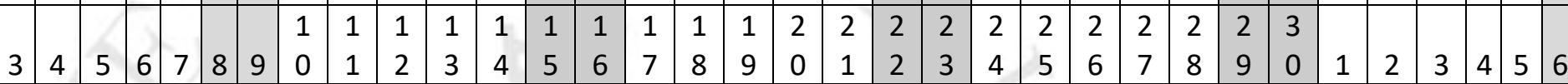

ATL

TELEVISIÓN

MENCIÓN

MUJERES AL MANDO (LATINA)

EN BOCA DE TODOS (AMÉRICA)

SPOT PUBLICITARIO

VALGAME DIOS (LATINA)

TENGO ALGO QUE DECIRTE

(LATINA)

TENGO ALGO QUE DECIRTE (LATINA)

EN BOCA DE TODOS (AMÉRICA)

DE VUELTA AL BARRIO (AMÉRICA)

ESTAS EN TODAS (AMÉRICA) EL ARTISTA DEL AÑO (AMÉRICA)

MAGALY TV LA FIRME (ATV)

PRENSA

EVENTO PRENSA

PUBLIREPORTAJE

REPORTE SEMANAL (LATINA)

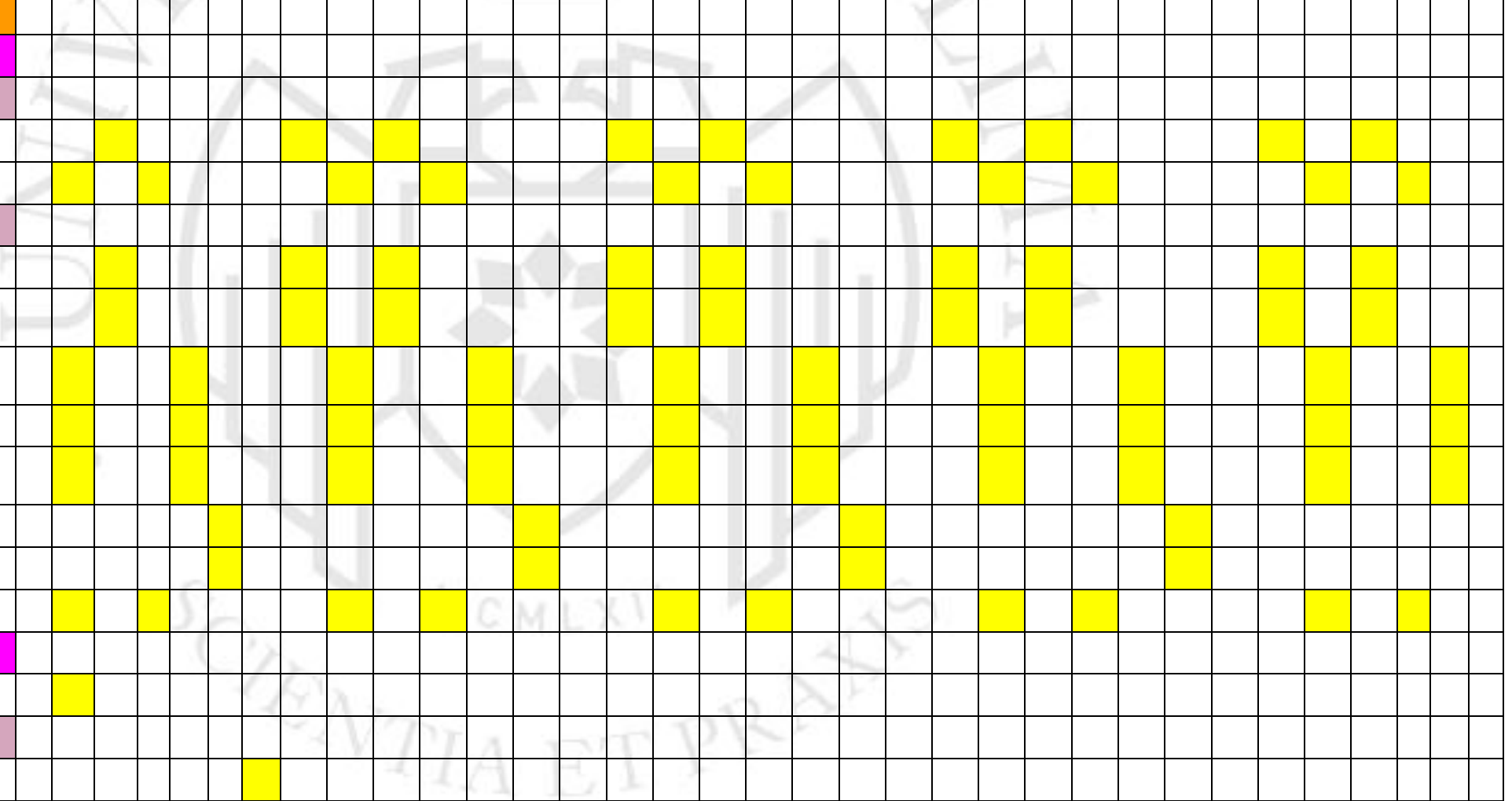




\begin{tabular}{|c|c|c|c|c|c|c|c|c|c|c|c|c|c|c|c|c|c|c|c|c|c|c|c|c|c|c|c|c|c|c|c|c|c|c|}
\hline SOMOS (EL COMERCIO) & & & & & & & & & & & & & & & & & & & & & & & & & & & & & & & & & & \\
\hline BTL & & & & & & & & & & & & L & & & 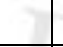 & + & & & & & & & & & & & & & & & & & & \\
\hline DEGUSTACIONES & & & & & & & & 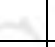 & & & & & & & & & & & & & & & & & & & & & & & & & & \\
\hline ACTIVACIONES & & & & & & & & 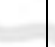 & & & 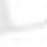 & 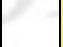 & & $H$ & - & + & & & & & & & & & & & & & & & & & & \\
\hline VALLAS & & & & & c & & & & & & & & & & & & & & & & & & & & & & & & & & & & & \\
\hline VISICOOLERS Y JALAVISTAS & & & & & & & & & & & & & & & & & & & & & & & & & & & & & & & & & & \\
\hline DIGITAL & & & 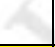 & & & & & & & & & & 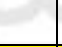 & te & & & & & & & r & & ג & & & & & & & & & & & \\
\hline PAUTA GOOGLE & & & & & & & & & & & & & & & & & & & & & & & & & & & & & & & & & & \\
\hline PAUTA FACEBOOK & & & & & & & & & & & & & & & & & & & & & & & & & & & & & & & & & & \\
\hline INFLUENCERS & 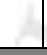 & & & & & & & - & & L & & & 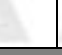 & 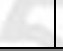 & t & 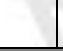 & & & & 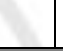 & & & 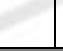 & & & & & & & & & & & \\
\hline & & & & & & & & & & & & & & & & & $\mathbf{U}$ & & & & & & & & & & & & & & & & & \\
\hline & $\mathrm{L}$ & $\mathrm{M}$ & $\mathrm{M}$ & $\mathrm{J}$ & $\mathrm{V}$ & $S$ & D & $\mathrm{L}$ & $\mathrm{M}$ & $\mathrm{M}$ & $\mathrm{J}$ & $\mathrm{V}$ & $\mathrm{S}$ & $\mathrm{D}$ & $\mathrm{L}$ & $\mathrm{M}$ & $\mathrm{M}$ & $\mathrm{J}$ & $\mathrm{V}$ & $\mathrm{S}$ & $\mathrm{D}$ & $\mathrm{L}$ & $\mathrm{M}$ & M & $\mathrm{J}$ & $\mathrm{V}$ & $\mathrm{S}$ & $\mathrm{D}$ & $\mathrm{L}$ & $\mathrm{M}$ & $\mathrm{M}$ & $\mathrm{J}$ & $\mathrm{V}$ & $\mathrm{S}$ \\
\hline & & & & & & & & & & 1 & 1 & 1 & 1 & 1 & 1 & 1 & 1 & 1 & 1 & 2 & 2 & 2 & 2 & 2 & 2 & 2 & 2 & 2 & 2 & 3 & 3 & & & \\
\hline & 1 & 2 & 3 & 4 & 56 & 6 & 7 & 8 & 9 & 0 & 1 & 2 & 3 & 4 & 5 & 6 & 7 & 8 & 9 & 0 & 1 & 2 & 3 & 4 & 5 & 6 & 7 & 8 & 9 & 0 & 1 & 1 & 2 & 3 \\
\hline ATL & & & & & & & & & & & - & & & 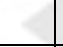 & & & & & & & 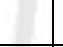 & & 1 & & & & & & & & & & & \\
\hline TELEVISIÓN & & & & & & & & & & & & & & & & & & & & & L & & & & & & & & & & & & & \\
\hline MENCIÓN & & & & & & & & & & 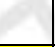 & & & & & & 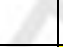 & & & & & & & & & & & & & & & & & & \\
\hline MUJERES AL MANDO (LATINA) & & & & & & & & & & & B & & & & & & & & & & & & 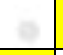 & & & & & & & & & & & \\
\hline EN BOCA DE TODOS (AMÉRICA) & & & & & & & & & & & & 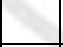 & & & 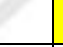 & & & & & & & & & & & & & & & & & & & \\
\hline SPOT PUBLICITARIO & & & & & & & & & & & & & & & & & & & & & & & & & & & & & & & & & & \\
\hline VALGAME DIOS (LATINA) & & & & & 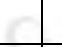 & & & & te & & & & & & & & & 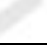 & & & 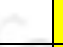 & & & & & & & & & & & & & \\
\hline $\begin{array}{l}\text { TENGO ALGO QUE DECIRTE } \\
\text { (LATINA) }\end{array}$ & & & & & & & & & & & & 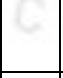 & 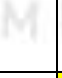 & 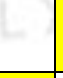 & & & & & & te & 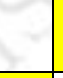 & & & & & & & & & & & & & \\
\hline REPORTE SEMANAL (LATINA) & & & & & & & & & & & & & & & & & & & t & & & & & & & & & & & & & & & \\
\hline EN BOCA DE TODOS (AMÉRICA) & & & & & & & & - & & & & & & & & & 2 & ( & & & & & & & & & & & & & & & & \\
\hline $\begin{array}{l}\text { DE VUELTA AL BARRIO } \\
\text { (AMÉRICA) }\end{array}$ & & & & & & & & & & [et & & & & & & & & & & & & & & & & & & & & & & & & \\
\hline
\end{tabular}




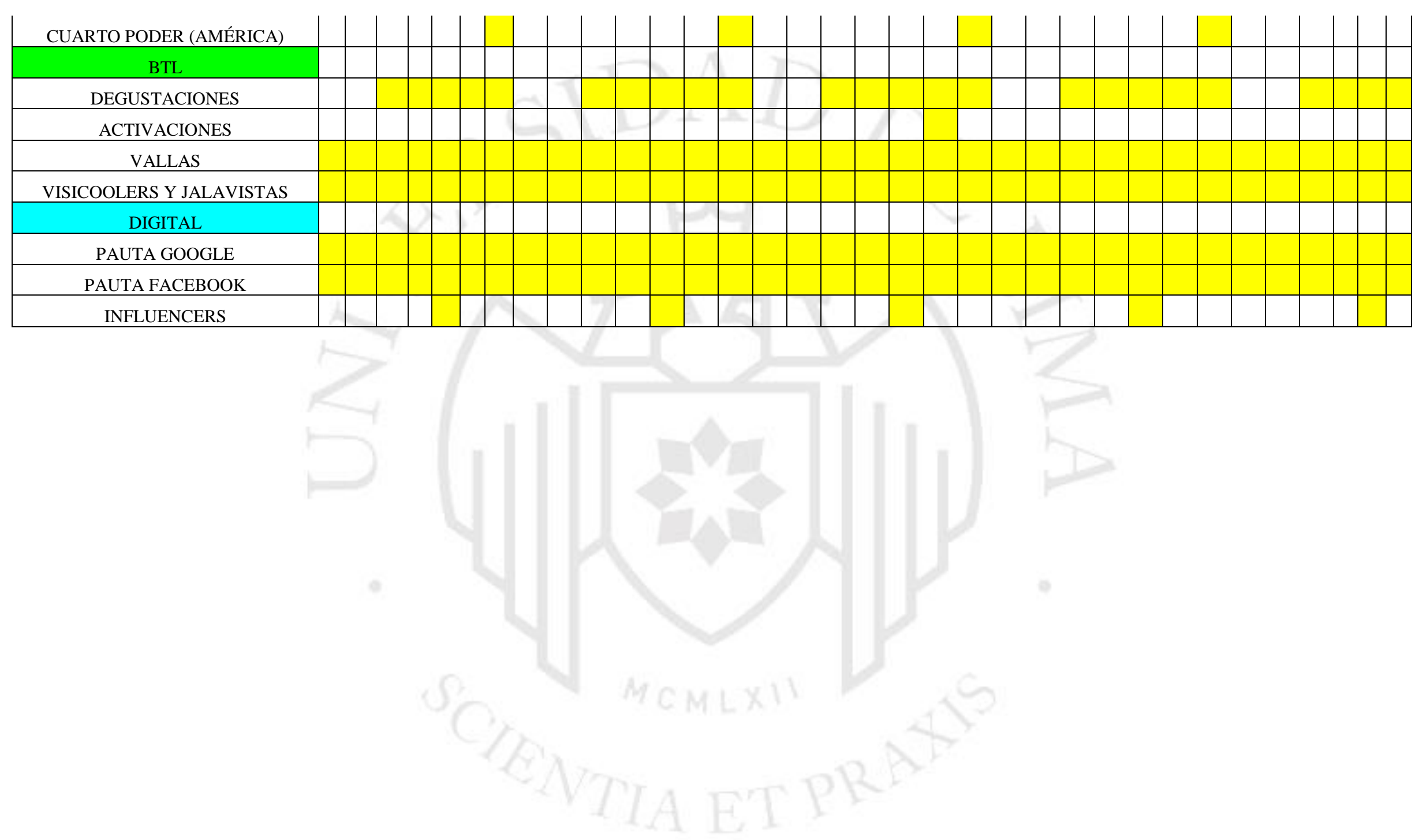




\section{CONCLUSIONES Y RECOMENDACIONES}

\subsection{Conclusiones}

- Según Ipsos,el número estimado de amas de casa en nuestro país es de 8 millones. Además, el $90 \%$ de ellas tienen hijos.

- La manera en la que se entretienen es compartiendo con sus pequeños mirando televisión visitando a familiares o amigos y realizando deportes. Por otro lado, los medios de comunicación que más consumen son los siguientes: televisión,en primer lugar,internet,en segundo lugar y radio en tercer lugar.

- Según Ipsos, en relación a sus hábitos de consumo, la mayoría de amas de casas deciden qué comprar en el instante. Los lugares a los que se dirigen con mayor frecuencia para realizar sus compras son supermercados y bodegas. Se han vuelto personas muy selectivas, valoran mucho los productos naturales y ya no se fijan en el precio si no en la calidad.

- La misión de marca de Quntu se basa en contribuir con la alimentación y la salud de las familias peruanas siendo un producto $100 \%$ natural que no contiene preservantes, saborizantes, ni azúcar añadida.

- La visión de marca de Quntu se basa en ser el concentrado de chicha morada 100\% natural, único en el mercado en relación a la competencia, puesto que no contiene saborizantes, preservantes, ni azúcar añadida. Está basado en la auténtica receta tradicional de chicha morada y contiene grandes beneficios para la salud.

- El concepto creativo de campaña, busca reflejar que Quntu es un concentrado 100\% natural basada en la auténtica receta tradicional de chicha morada y que contiene grandes beneficios para la salud.

- La campaña durará dos meses para ser más exactos durante Junio y Julio y será una campaña 360. El lanzamiento se realizará en las dos primeras semanas y el mantenimiento durante las semanas restantes, esto con el fin de cumplir con los objetivos de comunicación.

- Los medios de comunicación en los que estaremos más presentes durante los dos meses de campaña será en televisión e internet, pues el target los consume con mayor frecuencia. No se dejará de invertir en publicidad ooh como vallas, activaciones y degustaciones. 


\subsection{Recomendaciones}

- Las ferias naturales cada vez se vuelven más populares por lo que la marca deberá estar presente constantemente.

- Será importante realizar una alianza estratégica con algún producto con el fin de alcanzar ventajas competitivas y llegar a posicionarnos en la mente de nuestro consumidor.

- En un futuro se debe evaluar la posibilidad de auspiciar campañas de salud y/o ferias gastronómicas grandes como Mistura con la finalidad de cumplir con nuestra misión y visión de marca.

- Durante el verano se debe considerar colocar vallas en la panamericana sur pues es en esa temporada donde las familias suelen ir a la playa. Además, se realizará una campaña de mantenimiento con bastante presencia en medios pues es una excelente ocasión para que nuestro público objetivo consuma.

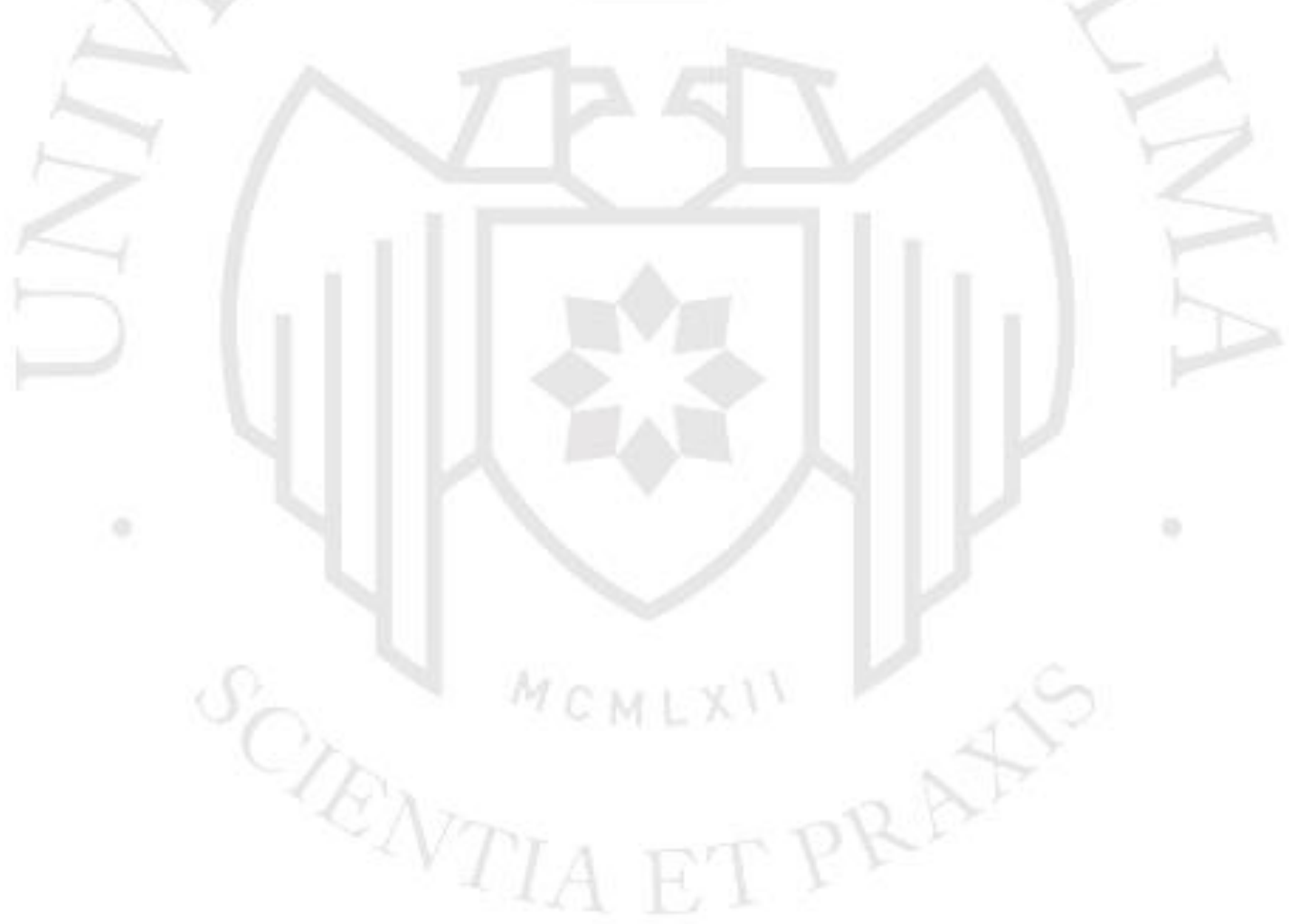




\section{BIBLIOGRAFÍA}

AECOC. (1 de Febrero de 2019). Los 4 perfiles del consumidor de productos ECO y BIO. (L. A. Distribuidores, Editor) Obtenido de Los 4 perfiles del consumidor de productos ECO y BIO: https://www.aecoc.es/articulos/los-4-perfiles-delconsumidor-de-productos-eco-y-bio/

Álvarez, J. (29 de Octubre de 2018). El $55 \%$ de amas de casa en Lima es internauta y tiene cuenta de Facebook. (Andina, Entrevistador) Obtenido de https://andina.pe/agencia/noticia-el-55-amas-casa-lima-es-internauta-y-tienecuenta-facebook-529436.aspx

APEIM. (1 de Abril de 2005). Asociación Peruana de Empresas de Investigación de Mercados. Obtenido de NIVELES SOCIOECONÓMICOS EN LIMA METROPOLITANA Y CALLAO : http://www.apeim.com.pe/wpcontent/themes/apeim/docs/nse/APEIM-NSE-2003-2004-LIMA.pdf

Arellano Marketing. (1 de Enero de 2019). Las Modernas. Obtenido de Los Seis Estilos De Vida: https://www.arellano.pe/los-seis-estilos-de-vida/las-modernas/

Cámara de Comercio de Lima. (2019). IMPORTACIÓN DE AGUA EMBOTELLADA SE DUPLICÓ DURANTE EL VERANO. Lima: La Cámara. Obtenido de https://www.camaralima.org.pe/repositorioaps/0/0/par/r872_3/comercio\%20exte rior\%20ok_final.pdf

Correo. (8 de Junio de 2018). Mujeres peruanas. Mujeres peruanas toman el Mujeres peruanas toman el $80 \%$ de las decisiones en el hogar, según Ipsos, pág. 1. Obtenido de https://diariocorreo.pe/peru/mujeres-peruanas-toman-80decisiones-hogar-segun-ipsos-823533/v

Cuerpo y mente. (1 de Enero de 2019). Portal cuerpo y mente. Obtenido de Maíz morado, el rey inca de los antioxidantes:

https://www.cuerpomente.com/alimentacion/superalimentos/maiz-morado_1340

El Comercio. (24 de Febrero de 2019). El Comercio. Obtenido de Octógonos de advertencia ¿Qué son y por qué serán obligatorios desde el 17 de junio?: https://elcomercio.pe/tecnologia/ciencias/octogonos-advertencia-sirven-seranobligatorios-junio-noticia-610351

El Peruano. (16 de Junio de 2018). Ley de promoción de la alimentación saludable para niños, niñas y adolescentes, y su Reglamento aprobado por Decreto Supremo $\mathrm{N}^{\mathrm{o}}$ 017-2017-SA. Aprueban Manual de Advertencias Publicitarias en el marco de lo establecido en la Ley $N^{o}$ 30021. Lima, Lima, Perú: El Peruano. Obtenido de https://busquedas.elperuano.pe/download/url/aprueban-manual-de-advertenciaspublicitarias-en-el-marco-de-decreto-supremo-n-012-2018-sa-1660606-1

García Nieto, J. P. (2013). Consturye tu Web comercial: de la idea al negocio. Madrid: RA-MA.

Gestión. (1 de Mayo de 2019). Bebidas suben 0.35\%. Alimentos y Bebidas suben 0.35\% en abril y llevan inflación a $0.20 \%$ en Lima Metropolitana, pág. 1. Obtenido de https://gestion.pe/economia/alimentos-bebidas-suben-0-35-abril-llevaninflacion-0-20-lima-metropolitana-265586

INEI. (12 de Mayo de 2017). Más del 60\% de las madres del país trabajan. Obtenido de Más del $60 \%$ de las madres del país trabajan: 
https://www.inei.gob.pe/prensa/noticias/mas-del-60-de-las-madres-del-paistrabajan-9714/

Instituo Nacional de Salud. (1 de Enero de 2019). Instituto Nacional de Salud. Obtenido de Aplicaciones Móviles CENAN: https://web.ins.gob.pe/es/alimentacion-ynutricion/aplicativo/moviles

Instituto Nacional de Salud. (1 de Enero de 2009). TABLAS PERUANAS DE COMPOSICIÓN DE ALIMENTOS. CENTRO NACIONAL DE ALIMENTACIÓN Y NUTRICIÓN INSTITUTO NACIONAL DE SALUD. Lima, Lima, Perú: INS.GOB. Obtenido de http://www.ins.gob.pe/insvirtual/images/otrpubs/pdf/Tabla\%20de\%20Alimentos .pdf

IPSOS. (1 de Mayo de 2017). ¿En qué ocupa su tiempo libre? Lima, Lima, Perú.

IPSOS. (15 de Junio de 2017). ¿Qué significa éxito para ti? Lima, Lima, Perú.

IPSOS. (1 de Febrero de 2017). El ama de casa: cada vez más jefa de hogar. Obtenido de El ama de casa: cada vez más jefa de hogar : https://www.ipsos.com/sites/default/files/2017-02/AmasDeCasaJefeHogar.pdf

IPSOS. (2017). Yo soy, el shopper peruano digitalizado. Lima: Ipsos. Obtenido de https://www.ipsos.com/sites/default/files/2017-

05/YoSoyElShopperPeruanoDigitalizado.pdf

IPSOS. (2 de Mayo de 2018). ¿Qué prefiere ver en la TV? Lima, Lima, Perú.

IPSOS. (11 de Mayo de 2018). Innovación y Conocimiento: Consumidor \& Cliente. Obtenido de Perfil del ama de casa peruana 2018: https://www.ipsos.com/espe/perfil-del-ama-de-casa-peruana-2018

Kantar Ibope Media. (3 de Marzo de 2018). La mujer peruana: Una consumidora multimedios y multipantalla. Obtenido de La mujer peruana: Una consumidora multimedios y multipantalla: https://www.kantaribopemedia.com/la-mujerperuana-una-consumidora-multimedios-y-multipantalla/

Kantar World Panel. (26 de Marzo de 2019). Consumo saludable. Obtenido de Hogares peruanos se orientan hacia consumo saludable:

https://www.kantarworldpanel.com/pe/Noticias/Hogares-peruanos-se-orientanhacia-consumo-saludable

La República. (23 de Noviembre de 2018). Tendencias de consumo. Conoce las tendencias que activarán el consumo en el 2019, pág. 1. Obtenido de https://larepublica.pe/marketing/1362912-conoce-tendencias-activaranconsumo-2019

La Voz de los Emprendedores. (24 de Noviembre de 2018). Paneles publicitarios: Recomendaciones y costos. Obtenido de Paneles publicitarios:

Recomendaciones y costos: https://www.pqs.pe/actualidad/noticias/panelespublicitarios-recomendaciones-y-costos

Lima Consulting. (1 de Enero de 2018). Estudio cuantitativo sobre consumo radial y televisivo nacional. (C. TV, Ed.) Obtenido de Estudio cuantitativo sobre consumo radial y televisivo nacional: http://www.concortv.gob.pe/wpcontent/uploads/2018/04/Estudio-Consumo-TVyRadio-2017.pdf

Media Kit. (1 de Enero de 2019). Grupo Editorial Criterio. Obtenido de Media kit 2019: http://e.gec.pe/67/doc/0/0/7/5/0/750799.pdf

Métrica. (14 de Mayo de 2018). El boom de las Mamás Blogueras en el Perú. Obtenido de El boom de las Mamás Blogueras en el Perú: https://metrica.pe/el-boom-delas-mamas-blogueras-peru/ 
Mott. (1 de Enero de 2019). Las amas de casa de Lima de hoy en día. Obtenido de Las amas de casa de Lima de hoy en día: https://mott.pe/noticias/las-amas-de-casade-lima-de-hoy-en-dia/

ONPE. (16 de Noviembre de 2015). Oficina Nacional de Procesos Electorales. Obtenido de Tarifas para publicidad política:

https://www.web.onpe.gob.pe/modFinanciamiento/Tarifas-Publicitarias/EEGG2016/Lima/TV/TV_Latina.pdf

ONPE. (3 de Febrero de 2016). Oficina Nacional de Procesos Electorales. Obtenido de Tarifas publicitarias electorales:

https://www.web.onpe.gob.pe/modFinanciamiento/Tarifas-Publicitarias/EEGG2016/Lima/TV/ATV-15feb.pdf

ONPE. (1 de Enero de 2016). Oficina Nacional de Procesos Electorales. Obtenido de Tarifario de publicidad en Vallas electorales:

https://www.web.onpe.gob.pe/modFinanciamiento/Tarifas-Publicitarias/EEGG2016/Lima/publicidad_exterior/Grupo_Vallas.pdf

Pérez, D., \& Ubago, I. P. (1 de Enero de 2006). Asociación de profesores independientes. Obtenido de Escuela de negocios: http://api.eoi.es/api_v1_dev.php/fedora/asset/eoi:45089/componente45087.pdf

Perú. (3 de Mayo de 2019). Perú. Obtenido de Marca Perú: https://peru.info/espe/gastronomia/noticias/2/12/maiz-morado-el-mas-poderoso-antioxidante

Peru Retail. (1 de Octubre de 2018). Tendencias de consumo. Obtenido de Tendencias de consumo en la industria de alimentos y bebidas: https://www.peruretail.com/tendencias-consumo-industria-alimentos-y-bebidas/

Pre Venta 2019. (1 de Enero de 2019). América TV comerciales. Obtenido de Pre venta 2019: https://www.comercial.americatv.com.pe/portafolio/1

Publímetro. (13 de Mayo de 2018). Día de la Madre: existen más de 186 blogs dirigidos por mamás peruanas. Obtenido de Día de la Madre: existen más de 186 blogs dirigidos por mamás peruanas: https://publimetro.pe/vidaestilo/noticia-dia-madre-existen-mas-186-blogs-dirigidos-mamas-peruanas74032

Publímetro. (29 de Junio de 2018). Inauguran la gran feria ecológica del Jockey Plaza. Inauguran la gran feria ecológica del Jockey Plaza, pág. 1. Obtenido de https://publimetro.pe/entretenimiento/noticia-inaguran-gran-feria-ecologicajockey-plaza- 75797

Radio Difusión. (1 de Enero de 2019). Radio difusión. Obtenido de Tarifas: https://www.radiodifusion.com/nosotros/tarifas/

runasimi. (1 de Mayo de 2019). Diccionário Quechua. Obtenido de Diccionário Quechua: http://www.runasimi.org/cgi-bin/dict.cgi?LANG=es.

SCielo Perú. (1 de Diciembre de 2015). Características de los consumidores de productos orgánicos y expansión de su oferta en Lima. Obtenido de Características de los consumidores de productos orgánicos y expansión de su oferta en Lima:

http://www.scielo.org.pe/scielo.php?script=sci_arttext\&pid=S025218652015000200002

Vidal, M. (4 de Julio de 2017). Más expuestas al entorno y activas en la economía. 2. (Gestión, Entrevistador, \& Gestión, Editor) Lima. Obtenido de https://www.inei.gob.pe/media/inei_en_los_medios/04_jul_Gestion_2-3a.pdf

Wolf, A. (21 de Agosto de 2017). Tres tendencias clave en alimentos envasados en América Latina. (E. Internacional, Entrevistador) Obtenido de https://www.youtube.com/watch?v=zuvOZMij3sI 


\begin{abstract}
ANEXOS
Anexo 1: Focus Group

Focus group realizado a 10 amas de casa. De ellas, 5 tenían entre 28 y 35 años y las otras entre 37 y 50 años. Fue realizado en dos etapas con cada grupo. La duración fue de 30 minutos y acá se ven algunos resultados.
\end{abstract}

Bebidas favoritas para dar a sus hijos

"Manzanilla porque a mi hija le gustan las infusiones y a la vez porque no tiene preservantes"

"A veces le mando agua otro día limonada o yogurt trato siempre de variar para que no se aburra"

"Ninguna envasada. Refresco natural."

"Agua, para que le baje el azúcar porque se pone hiperactiva"

"Jugo de naranja, maracuyá, limonada o aquarius. Siempre les doy bebidas saludables"

"Yogurt porque es bueno darles lácteos"

"Refresco porque es más saludable. Suelo consumir todo natural y bajo en azúcar"

"Limonada, maracuyá; porque son más fáciles de preparar en el momento"

"Refrescos siempre, no le gusta la leche"

"Siempre lácteos, para la media mañana un refresco"

Sobre las bebidas nutritivas

"Que son lo mejor para nuestro cuerpo porque nos aportan nutrientes"

"No las consumo, prefiero un refresco o agua"

"Decido comprar siempre insumos naturales y/u orgánicos. Me preocupa la alimentación de mis hijos"

"Necesarias para la salud y alimentación. Quiero cuidar mi alimentación"

"De preferencia jugos naturales, no las bebidas "nutritivas" que venden en el super, pero si falta tiempo una bebida que no tenga demasiados colorantes"

"Mejora su metabolismo"

"Aportan mayor beneficio para la alimentación"

"Que algunas por su buen sabor pueden servir como un aporte nutricional extra y de fácil consumo, sobre todo para los niños que no son muy amantes de las verduras o alimentos con alto valor nutritivo" "Creo que es lo mejor que ha podido salir al mercado"

"Se del aloe, pero no me gusta su sabor. Prefiero los extractos frutados"

¿Agua o bebida con sabor?

"La verdad no, mayormente toma chicha o limonada ya que no le gusta el agua pura"

"Agua o refresco de frutas naturales"

"Solo agua para bajarle la energía"

"Trato de darle refrescos naturales porque es más saludable y tiene sabor"

"De preferencia agua el resto del día, pero con su almuerzo está bien algo con sabor"

"Agua, en fiestas puede ser un gaseosa"

"Bebida con sabor por costumbre"

"Suelo darle agua pura durante el día, porque siento que es lo más natural que puedo brindar y a la vez calma bastante la sed producto de los constantes juegos y actividades que realiza durante el día propios de su edad"

"Siempre piden con sabor, a veces los engaño con agua"

"Con alimentos les permito gaseosa o refresco, pero durante el día, especialmente en la noche, siempre es agua porque si no están muy hiperactivos"

¿Comprarías un concentrado de chicha natural? 
"Si, y es lo que todos tomamos en casa"

"Si. No suelo preparar bebidas naturales demandan mucho tiempo por eso le doy agua chocolatada o yogurt, pero si sabe igual perfecto"

"No. Prefiero hervir yo el maíz"

"A veces por el tiempo"

"No, prefiero lo natural"

"Si, porque es natural y fácil de preparar"

"Si, porque es natural y sano"

"Si es confiable, de sabor agradable, de buena calidad y $100 \%$ natural podría optar por incluirlo como refresco para sus almuerzos"

"Nunca he comprado, pero no sería una mala idea. La chicha porque es un refresco clásico y siempre les gusta a todos"

"Si me va ayudar a reducir tiempo de preparación, sí"

¿Qué esperas de un concentrado de chicha?

"Que sea $100 \%$ natural y que no tenga preservantes"

"No he consumido antes uno, pero de un concentrado de fruta, que sea rico obvio"

"Refresque, nada más"

"Que el gusto sea muy parecido al de maíz"

"Que sea de fácil preparación y que sea natural, que venga ya endulzado con algún producto natural también para que sea instantáneo, y que el sabor sea tal cual como la preparación tradicional, con su gustito a piña y canela"

"Que no pierda el sabor natural del maíz morado"

"Que sea totalmente natural"

"Que el concentrado esté libre de colorantes, y saborizantes artificiales, que sea de fácil preparación, que se conserve a temperatura ambiente, que no provoque alergias y que su presentación sea en cantidades variadas y con abre fácil para conservar la higiene en caso no desee preparar todo el concentrado"

"Sabor, que no sea artificial como las otras chichas instantáneas".

"Sabor, principalmente, sabor"

El cuidado de tu salud ¿qué puede aportar la chicha morada?

"Energía, nutrientes"

"No consumimos bebidas envasadas, pero sé que la chicha es buen antioxidante"

"Si va aportar algo, que rehidrate. Ahora consumen Gatorade porque practican deporte"

"Vitaminas y proteínas"

"Que no tenga químicos que dañen la salud y si viene con vitaminas mucho mejor"

"Que aporte energía. Este producto parece que tiene varios beneficios"

"Que calme la sed y acompañe nuestros alimentos sin afectar la salud .Las gaseosas no calman la sed y afectan la salud"

"Básicamente vitaminas y que sea una bebida natural, ya que solo es un complemento, la salud se cuida con una buena alimentación, deporte y vida sana"

"Primero que hidrate, es su principal función. que ayude a la alimentación y no la degenere como las gaseosas"

"Sé que el maíz morado es bueno, pero en verdad no se cuales son esos valores nutritivos. espero que aporte a su alimentación de mis hijos"

¿Qué opinas de Naturale?

"Me gustó mucho el sabor"

"Fácil de preparar y rinde para mi familia"

"Prepare el producto en la fiesta de mi hijo y a todos les gustó"

"Un poco artificial, prefiero preparar la chicha yo misma"

"No me gusta"

"En el super siempre lo venden, no me disgusta pero no es mi favorito"

"Sí, lo compro pero para no consumir algo más artificial"

"Alguna vez lo tome, pero no soy fan" 
"No parece un buen producto

"Prefiero las bebida hechas por mi"

Anexo 2: Encuestas sobre el nombre

¿Cómo nombraría a este CONCENTRADO de chicha morada?

65 respuestas

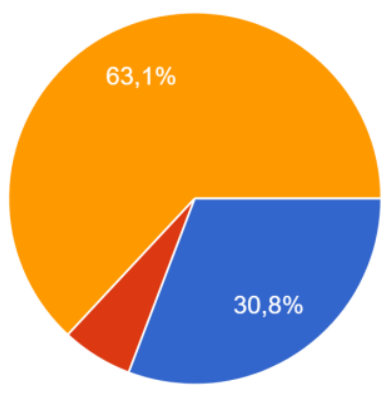

Mi Morena

+ Zumo

Quntu: significa "aroma" en quechua

¿Por qué eligió este nombre?

65 respuestas

Estas son las palabras claves que usaron como respuesta para Quntu:

\begin{tabular}{|c|c|c|c|c|c|}
\hline Ancestral & Peruanidad & Carácter & Sonido & Armonía & Significado \\
\hline Quechua & Orgánico & Interesante & Fácil & Llamativo & Distinto \\
\hline Auténtico & Tradicional & Importante & Comercial & & \\
\hline
\end{tabular}

\section{Anexo 3: Guión Spot publicitario}

SPOT TV - 45"

Concepto: Quntu, cuida la receta, cuida tu familia

\begin{tabular}{|l|l|l|l|l|}
\hline \multicolumn{1}{|c|}{$\begin{array}{c}\text { ṔLANO/ } \\
\text { ÁNGLO }\end{array}$} & \multicolumn{1}{c|}{ IMAGEN } & \multicolumn{1}{c|}{ TEXTO } & TONIDO \\
\hline $\begin{array}{l}\text { Plano conjunto } \\
\text { Ángulo Frontal } \\
\text { (La cámara va } \\
\text { haciendo zoom in) }\end{array}$ & $\begin{array}{l}\text { María Pía se } \\
\text { encuentra sentada } \\
\text { en su cama y con } \\
\text { pijama }\end{array}$ & $\begin{array}{l}\text { "Nosotras las } \\
\text { mamás hacemos de } \\
\text { todo por nuestros } \\
\text { hijos" }\end{array}$ & $\begin{array}{l}\text { Música de fondo } \\
\text { instrumental }\end{array}$ & 3 ' \\
\hline $\begin{array}{l}\text { Plano Medio } \\
\text { Ángulo Frontal } \\
\text { (Cámara estática) }\end{array}$ & $\begin{array}{l}\text { María Pía se quita } \\
\text { la colcha que lleva } \\
\text { sobre sus piernas y } \\
\text { con la colcha tapa } \\
\text { la cámara para }\end{array}$ & $\begin{array}{l}\text { "Nos levantamos } \\
\text { temprano" }\end{array}$ & $\begin{array}{l}\text { Música de fondo } \\
\text { instrumental }\end{array}$ & 2 ' \\
\hline
\end{tabular}




\begin{tabular}{|c|c|c|c|c|}
\hline & $\begin{array}{l}\text { aparecer en otra } \\
\text { locación }\end{array}$ & & & \\
\hline $\begin{array}{l}\text { Plano conjunto } \\
\text { Ángulo Frontal }\end{array}$ & $\begin{array}{l}\text { María Pía se } \\
\text { encuentra en la } \\
\text { cocina cerrando la } \\
\text { lonchera de su hija } \\
\text { camina un poco } \\
\text { pisa un juguete y lo } \\
\text { recoge }\end{array}$ & $\begin{array}{l}\text { 'Preparamos la } \\
\text { lonchera y (sonido) } \\
\text { recogemos lo que } \\
\text { siempre dejan } \\
\text { tirado pero siempre } \\
\text { ", }\end{array}$ & $\begin{array}{l}\text { Música de fondo } \\
\text { instrumental } \\
\text { Efecto de sonido de } \\
\text { un juguete para } \\
\text { niños }\end{array}$ & 5, \\
\hline $\begin{array}{l}\text { Plano conjunto } \\
\text { Ángulo Frontal }\end{array}$ & $\begin{array}{l}\text { Entra Catalina su } \\
\text { hijita y le jala la } \\
\text { blusa }\end{array}$ & "Mami, tengo sed" & $\begin{array}{l}\text { Música de fondo } \\
\text { instrumental }\end{array}$ & $2^{\prime}$ \\
\hline $\begin{array}{l}\text { Plano conjunto } \\
\text { Ángulo Frontal }\end{array}$ & $\begin{array}{l}\text { María Pía sonríe, } \\
\text { le agarra de la } \\
\text { mano a su hija y se } \\
\text { dirigen al comedor } \\
\text { La niña se sienta y } \\
\text { María Pía echa el } \\
\text { producto en una } \\
\text { jarra llena de agua }\end{array}$ & $\begin{array}{l}\text { "Estamos } \\
\text { pendientes que } \\
\text { crezcan sanos por } \\
\text { eso yo les doy } \\
\text { alimentos 100\% } \\
\text { naturales y Quntu } \\
\text { es uno de ellos" }\end{array}$ & $\begin{array}{l}\text { Música de fondo } \\
\text { instrumental }\end{array}$ & $6^{\prime}$ \\
\hline Animación & $\begin{array}{l}\text { Se muestra en } \\
\text { pantalla como los } \\
\text { ingredientes de } \\
\text { Quntu como el } \\
\text { maíz morado el } \\
\text { membrillo la piña } \\
\text { la canela el clavo y } \\
\text { el limón se mezclan } \\
\text { y dan vuelta } \\
\text { apareciendo la } \\
\text { botella de Quntu }\end{array}$ & $\begin{array}{l}\text { María Pía: '(Voz } \\
\text { en Off) 'Quntu es } \\
\text { un concentrado que } \\
\text { está elaborada por } \\
\text { la receta tradicional } \\
\text { casera de chicha } \\
\text { morada" }\end{array}$ & $\begin{array}{l}\text { Música de fondo } \\
\text { que acompañe la } \\
\text { animación }\end{array}$ & 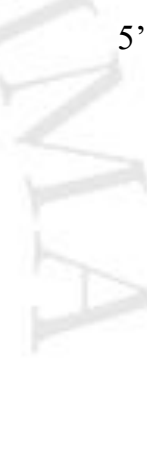 \\
\hline Animación & $\begin{array}{l}\text { Al lado de la } \\
\text { botella aparece en } \\
\text { texto y animado: } \\
\text { sin saborizante, ni } \\
\text { preservantes, ni } \\
\text { azúcar añadida }\end{array}$ & $\begin{array}{l}\text { María Pía: '(Voz } \\
\text { en Off) 'Pero lo } \\
\text { mejor de todo es } \\
\text { que no contiene } \\
\text { preservantes, ni } \\
\text { saborizantes, ni } \\
\text { azúcar añadida"' }\end{array}$ & $\begin{array}{l}\text { Música de fondo } \\
\text { que acompañe la } \\
\text { animación }\end{array}$ & $\theta$ \\
\hline $\begin{array}{l}\text { Plano conjunto } \\
\text { Ángulo frontal }\end{array}$ & $\begin{array}{l}\text { María Pía se } \\
\text { encuentra en el } \\
\text { comedor sirve un } \\
\text { vaso con Quntu y } \\
\text { se lo da a la niña } \\
\text { luego mira a la } \\
\text { cámara y señala } \\
\text { (haciendo alusión a } \\
\text { lo que dice) finaliza } \\
\text { acariciando la } \\
\text { cabecita de su niña, } \\
\text { mientras ella toma } \\
\text { su chicha }\end{array}$ & $\begin{array}{l}\text { "Es } 100 \% \text { natural } \\
\text { si } 100 \% \text { natural } \\
\text { como hecha por ti y } \\
\text { beneficia la salud } \\
\text { de tus hijos" }\end{array}$ & $\begin{array}{l}\text { Música de fondo } \\
\text { instrumental }\end{array}$ & 5, \\
\hline
\end{tabular}




\begin{tabular}{|l|l|l|l|c|}
\hline $\begin{array}{l}\text { Plano Conjunto } \\
\text { Ángulo Frontal }\end{array}$ & $\begin{array}{l}\text { María Pía y } \\
\text { Catalina juntas en } \\
\text { el comedor }\end{array}$ & $\begin{array}{l}\text { María Pía: "¿Que } \\
\text { tal estuvo, Cata?" } \\
\text { Cata: "Buenazo, } \\
\text { mami" }\end{array}$ & $\begin{array}{l}\text { Música de fondo } \\
\text { instrumental }\end{array}$ & 3, \\
\hline $\begin{array}{l}\text { Plano Conjunto } \\
\text { Ángulo Frontal } \\
\text { (La cámara se va } \\
\text { acercando hacia un } \\
\text { Plano medio) }\end{array}$ & $\begin{array}{l}\text { María Pía y } \\
\text { Catalina juntas en } \\
\text { el comedor }\end{array}$ & $\begin{array}{l}\text { "Ahhh y rinde para } \\
\text { 2.5 litros de } \\
\text { agua"iQué más } \\
\text { puedes pedir? }\end{array}$ & $\begin{array}{l}\text { Música de fondo } \\
\text { instrumental }\end{array}$ & 4, \\
\hline & $\begin{array}{l}\text { La imagen de } \\
\text { María Pía y } \\
\text { difumina ye sale al } \\
\text { frente la botella de } \\
\text { Quntu y el slogan }\end{array}$ & $\begin{array}{l}\text { María Pía: "Quntu, } \\
\text { auténtica receta } \\
\text { tradicional" }\end{array}$ & $\begin{array}{l}\text { Música de fondo } \\
\text { instrumental }\end{array}$ & 4, \\
\hline
\end{tabular}

\section{Anexo 4: Storyboard spot publicitario}
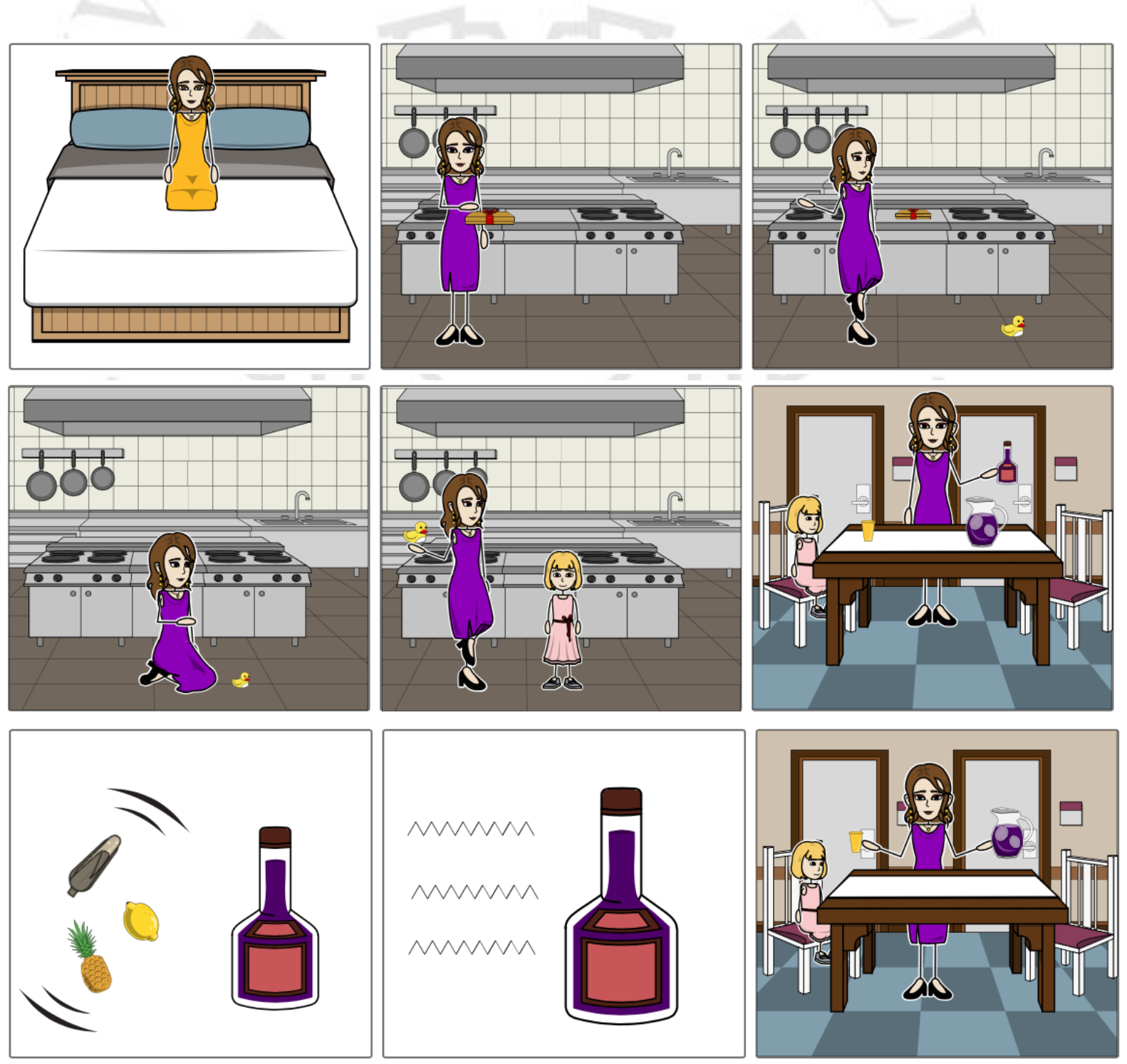
Anexo 5: Guión spot radial

\begin{tabular}{|c|c|c|}
\hline SONIDO & TEXTO & TIEMPO \\
\hline Música Instrumental divertida & $\begin{array}{l}\text { María Pía: Nosotras las mamás } \\
\text { sabemos que hacemos de todo por } \\
\text { nuestros hijos pero sobretodo } \\
\text { queremos que crezcan sanitos }\end{array}$ & $5^{\prime \prime}$ \\
\hline $\begin{array}{l}\text { Efecto de sonido que da pie al } \\
\text { texto de la hija de María Pía }\end{array}$ & Catalina: Mami tengo sed & $2^{\prime \prime}$ \\
\hline $\begin{array}{l}\text { Música Instrumental divertida } \\
\text { Efecto de sonido que simule } \\
\text { sirviendo un vaso con chicha } \\
\text { morada }\end{array}$ & $\begin{array}{l}\text { María Pía: Por eso yo le doy } \\
\text { alimentos } 100 \% \text { naturales como } \\
\text { Quntu - "Toma Catita" }\end{array}$ & $5^{\prime \prime}$ \\
\hline Música Instrumental divertida & $\begin{array}{l}\text { Quntu es un concentrado sin } \\
\text { preservantes, ni saborizantes, ni } \\
\text { azúcar añadida y sobretodo es } \\
100 \% \text { natural, si } 100 \% \text { natural } \\
\text { como hecho por ti. Ahhh y rinde } \\
\text { para } 2 \text { litros y medio de agua }\end{array}$ & $8^{\prime \prime}$ \\
\hline Música Instrumental divertida & $\begin{array}{l}\text { María Pía: Que tal estuvo Cata } \\
\text { Catalina: Buenazo mami }\end{array}$ & $3^{\prime \prime}$ \\
\hline Música Instrumental divertida & $\begin{array}{l}\text { María Pía: Yo preparo Quntu para } \\
\text { toda mi familia y ¿tu? }\end{array}$ & $4^{\prime \prime}$ \\
\hline Música Instrumental divertida & Quntu, auténtica receta tradicional & $3^{\prime \prime}$ \\
\hline
\end{tabular}

\section{Anexo 6: Infografía para revistas}

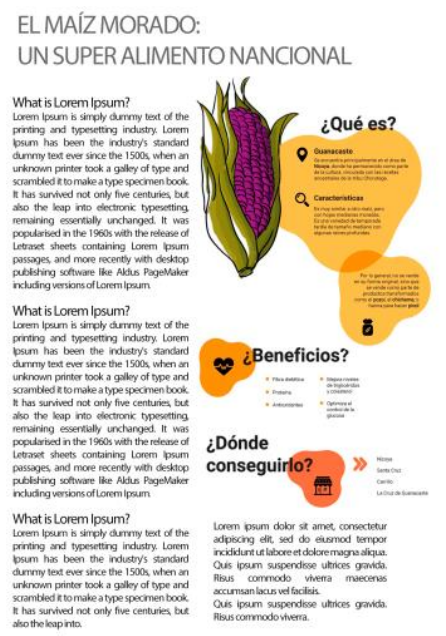


Anexo 7: Merchandising

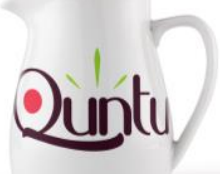

Quinto

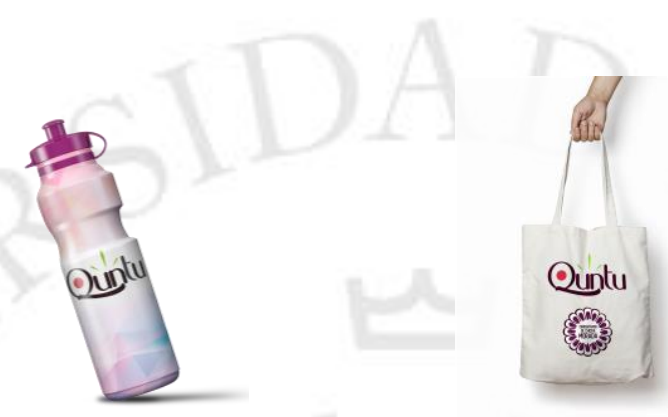

Anexo 8: Visual merchandising

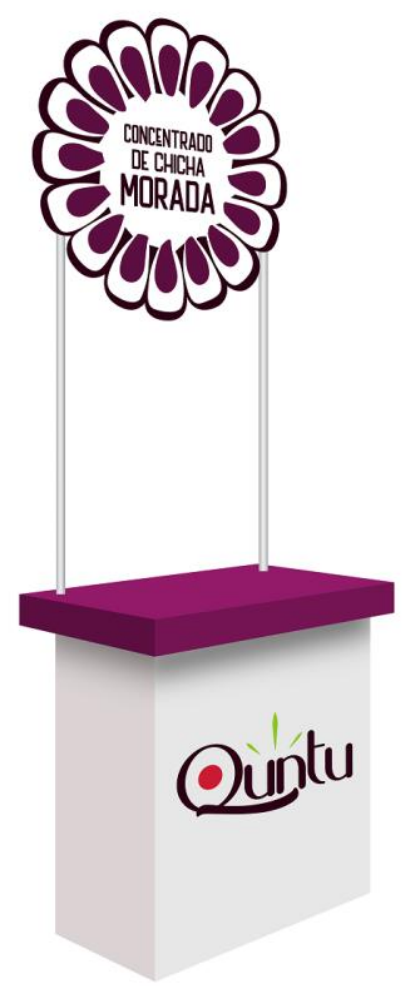




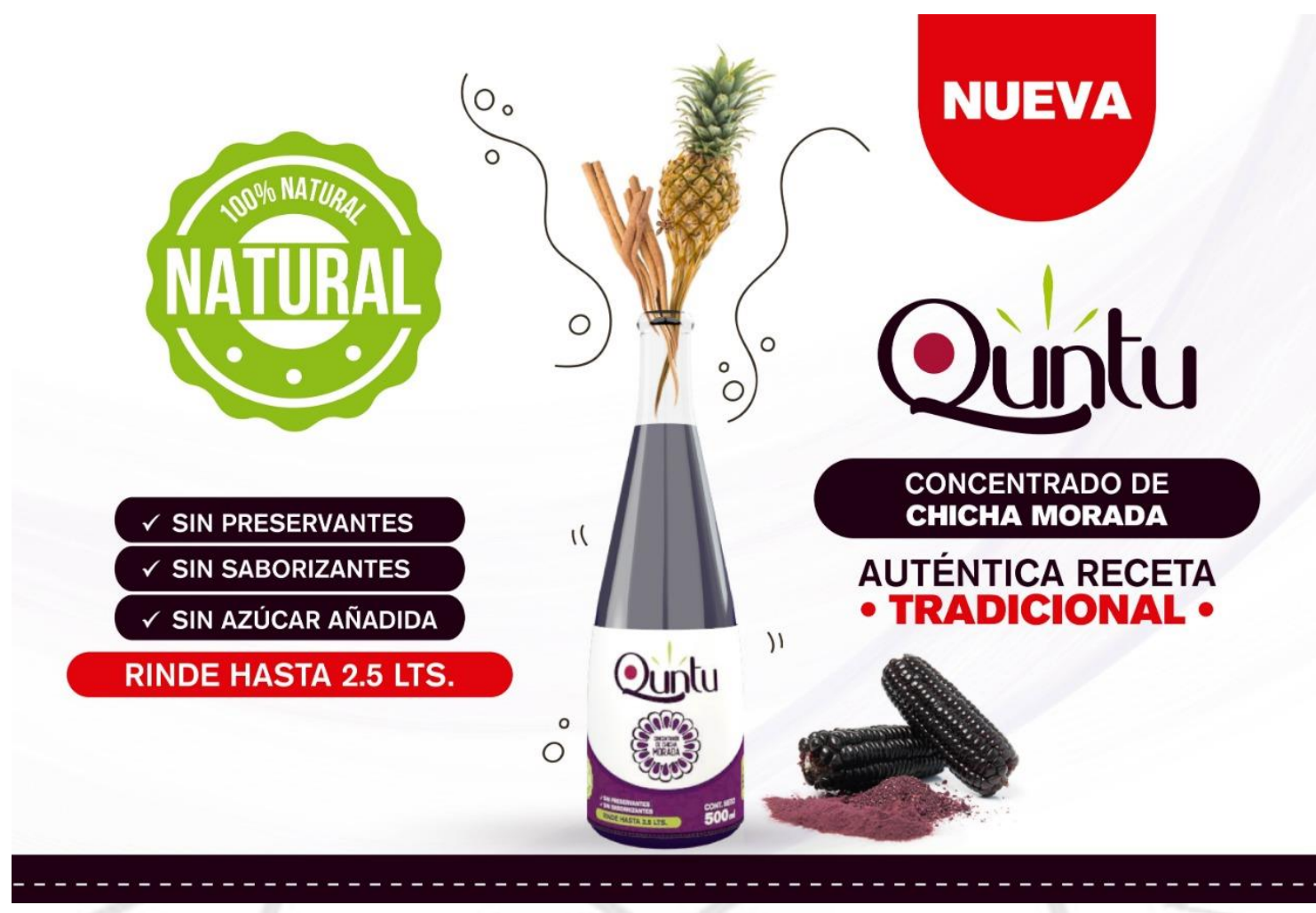

Anexo 10: Visicooler

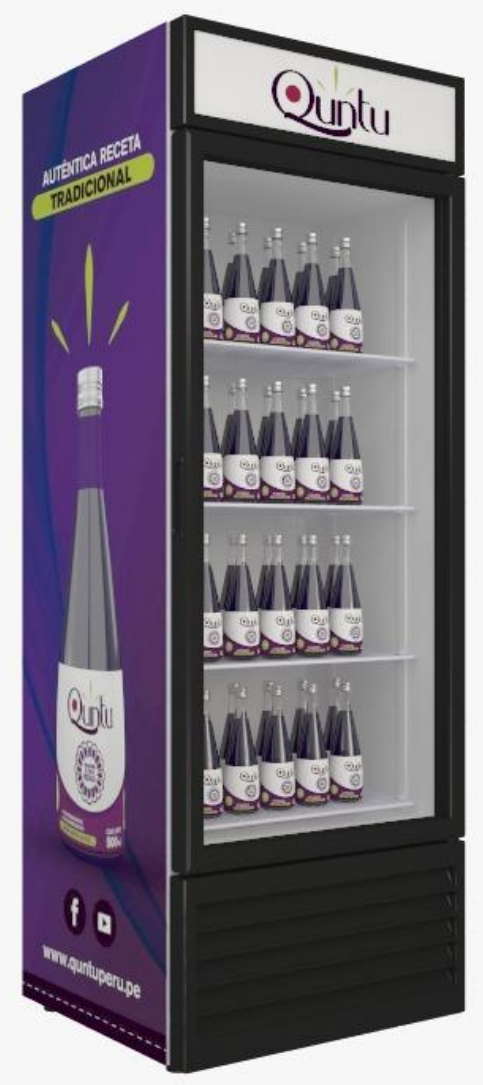


Anexo 11: Referencias mommy bloggers
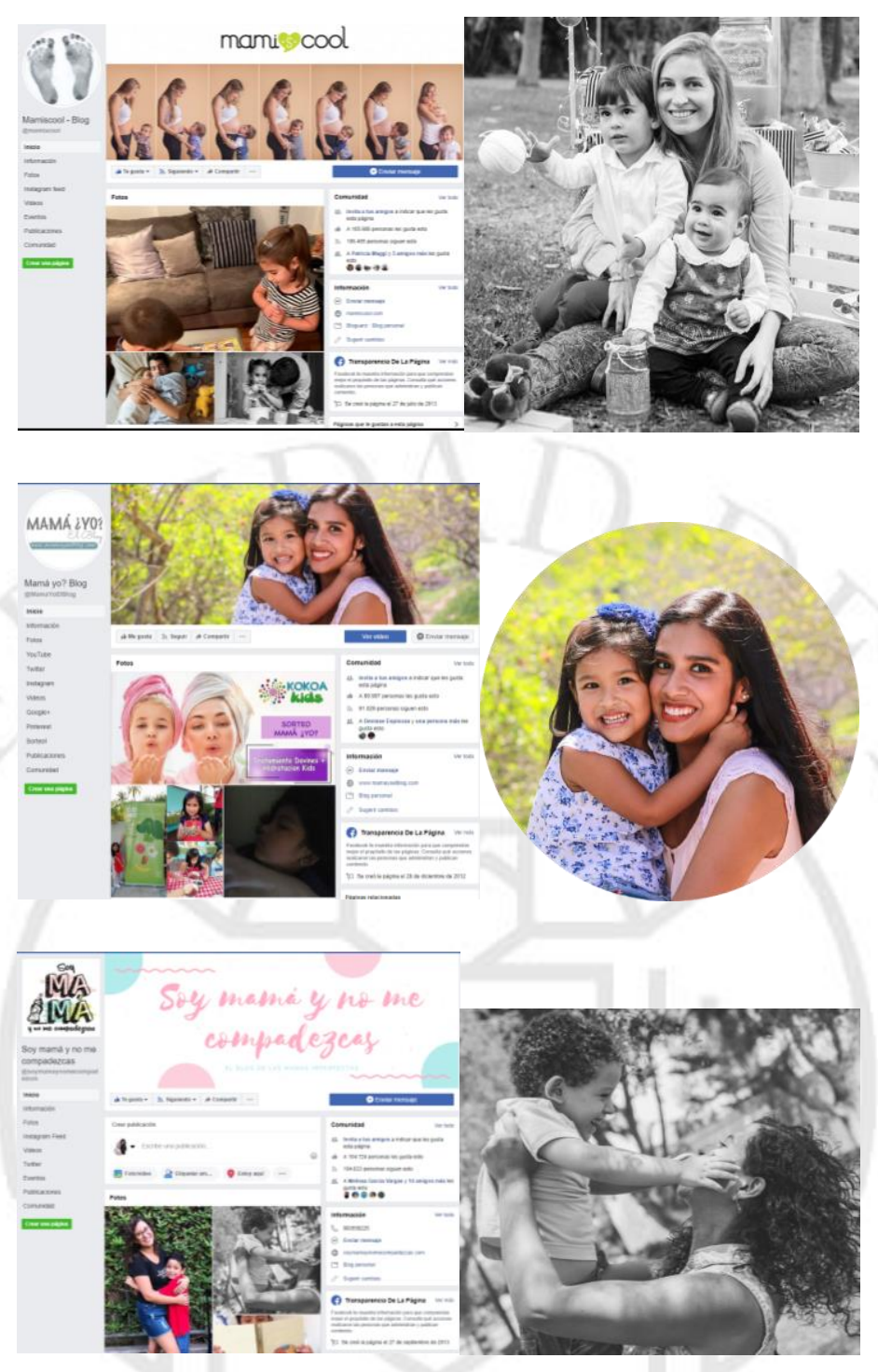


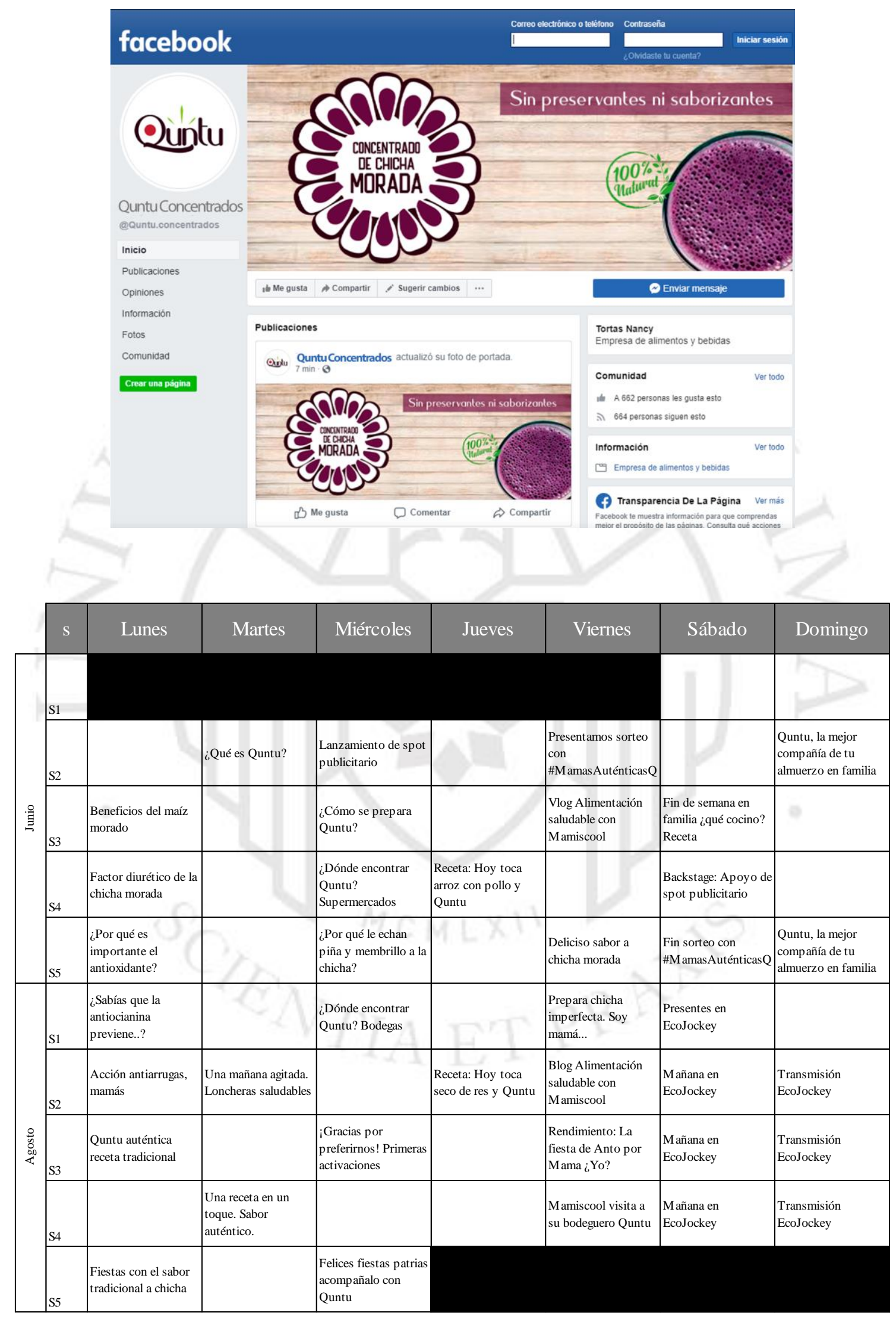




\section{Pautas en Facebook}

Pauta del spot publicitario

\section{Quidu Quntu concentrados \\ Publicidad - 9}

Conoce con María Pia la auténtitca receta tradicional de chicha morada ahora en concentrado.

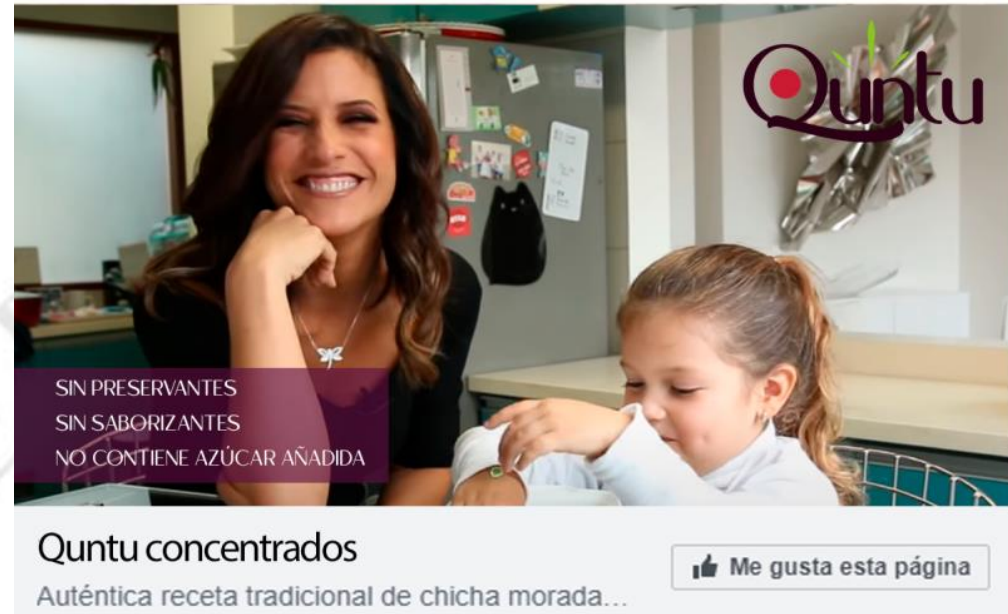

Auténtica receta tradicional de chicha morada....
De gusta
$\square$ Comentar
$\Rightarrow$ Compartir

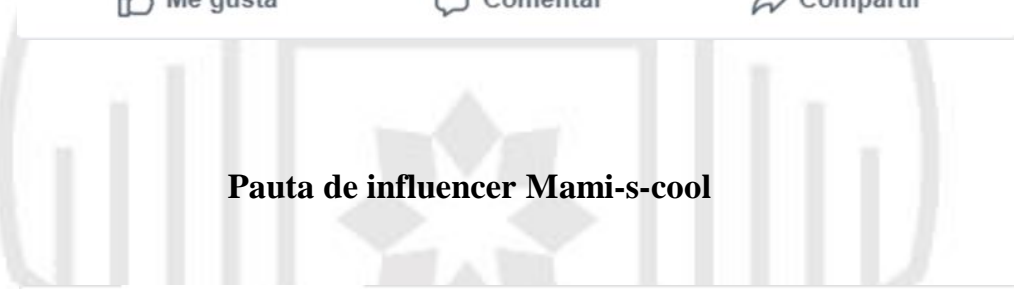

\section{Quntu concentrados \\ Publicidad . 6}

Conoce los beneficios de la chicha morada en el video de Mamiscool con Kristin Morris y sus pequeños

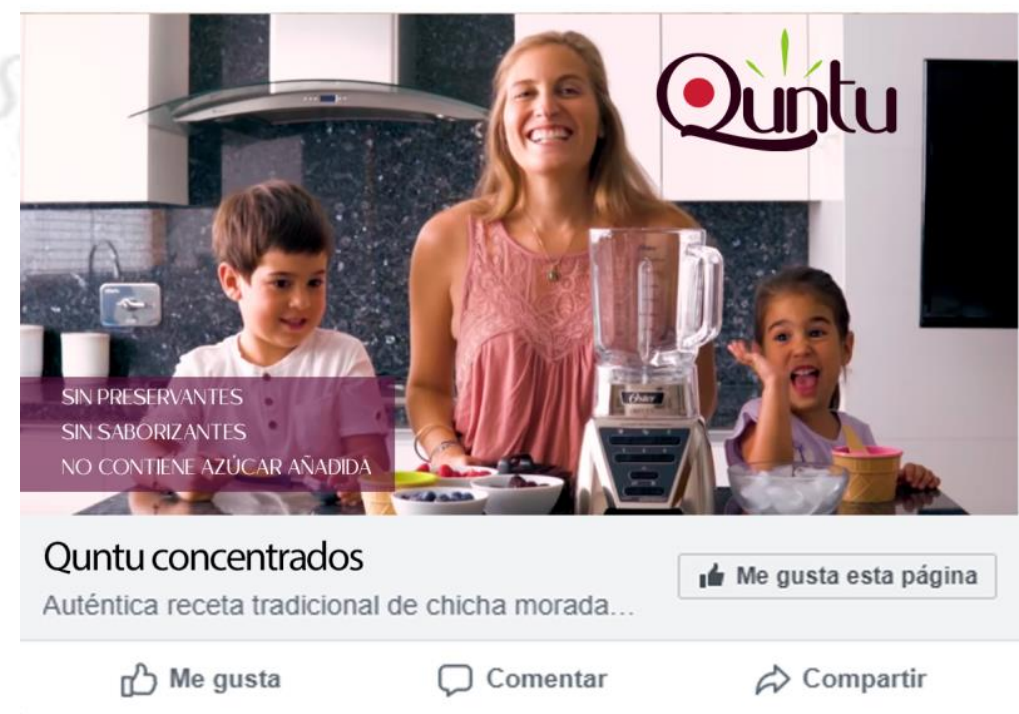

